\title{
34. CRETACEOUS NANNOPLANKTON BIOSTRATIGRAPHY AND OCEANOGRAPHY OF THE NORTHWESTERN ATLANTIC OCEAN
}

\author{
Peter H. Roth, Department of Geology and Geophysics, University of Utah, Salt Lake City, Utah
}

\begin{abstract}
A tentative Cretaceous nannoplankton zonation is given and the biostratigraphic extent of classical European and newly proposed oceanic stages as well as radiometric ages for important paleontological events and geochronologic boundaries are presented. Calcareous nannoplankton distribution at Sites 390 and 391 is discussed. The evolutionary lineage of Lithraphidites carniolensis- $L$. praequadratus- $L$. quadratus is used for the biostratigraphic subdivision of the uppermost Bermudan Stage. A working hypothesis of Cretaceous nannoplankton evolution and oceanography of the Cretaceous oceans is discussed. One new genus (Haqius) and two new species (Lithraphidites praequadratus and Cyclagelosphaera bergeri) are proposed. The evolution of Retecapsa during the Early Cretaceous is discussed and light micrographs are provided for $R$. neocomiana, $R$. angustiforata, and $R$. brightonii.
\end{abstract}

\section{INTRODUCTION}

Cores recovered during Leg 44 provide one of the most complete Lower Cretaceous sections in the Western Atlantic. (Figure 1 shows location of the Leg 44 sites.) The Lower Cretaceous limestones from Hole 391C contain rich assemblages of moderately well preserved nannofossil assemblages similar to the ones studied by Thierstein (1971, 1973) in sections from central and western Europe. Mid-Cretaceous sediments-ranging in age from about 108 m.y. to $102 \mathrm{~m} . \mathrm{y}$. and belonging to the Magellanian and Argusian stages - contain rich assemblages at the shallower Site 390 , but slightly more poorly preserved assemblages in the sapropellites at Site 391. Sediments ranging in age from $102 \mathrm{~m} . y$. to $72 \mathrm{~m} . \mathrm{y}$. were not recovered during Leg 44 . All samples were studied in the light microscope and only rough estimates of fossil abundance were made. The range charts presented are preliminary and show partly "filled" ranges; if a sample lacked a species as a result of poor preservation, but the particular species had a more or less continuous range above and below the particular sample the range of the species is shown as continuous.

Lower Cretaceous calcareous nannoplankton assemblages are rich in potentially useful species, especially groups related to Retecapsa, Cretarhabdus, and Zygodiscus. Studies with the electron microscope comparing the moderately well preserved assemblages with better preserved and admirably well described coccolith assemblages from the Speeton and Gault Clay of Great Britain (Black, 1971, 1972, 1973, 1975) should provide a more refined biostratigraphy for the Lower Cretaceous. In the appendix to this paper I briefly discuss some of my species concepts for Retecapsa, Cretarhabdus, and some of the species of Cyclagelosphaera.

\section{CRETACEOUS CALCAREOUS NANNOPLANKTON BIOSTRATIGRAPHY}

Recent improvements of calcareous plankton stratigraphy, summarized by van Hinte (1976a), have provided the most detailed worldwide time-frame for the Cretaceous. Planktic foraminifers and calcareous nannoplankton have a more widespread geographic distribution and show less provincialism than nektic and benthic organisms. Planktic biocoenoses are mostly controlled by surface temperature distribution. The relatively equable oceanic climate during the Cretaceous resulted in a fairly wide tropical zone where calcareous planktic organisms thrived. The traditional guide fossils for the Cretaceous (nektic cephalopods and belemnites; benthic foraminifers and echinoids) show more regional distribution. Thus, it has been necessary to establish boreal and Tethyan ammonite zonations (see van Hinte, 1976a). Planktic foraminifers reappear in the upper Hauterivian. In the Berriasian and Valanginian calpionellids serve as useful index microfossils. Benthic foraminifers are much more facies controlled and are therefore much less reliable age indicators. A secondary factor controlling calcareous plankton distribution is nearness to shore or a "neritic effect." Nearshore planktic foraminifer assemblages are dominated by hedbergellids (Douglas, 1972). Neritic calcareous nannoplankton in the Cretaceous include nannoconids and braarudosphaerids (Roth, 1973, in press; Thierstein, 1976). These forms are less reliable age indicators than oceanic nannoplankton groups.

We presently do not know which physical and chemical factors are responsible for the neritic (nearshore) effect. Higher fertility, greater turbidity, or more variable salinity in the neritic environments seem to be the most important 


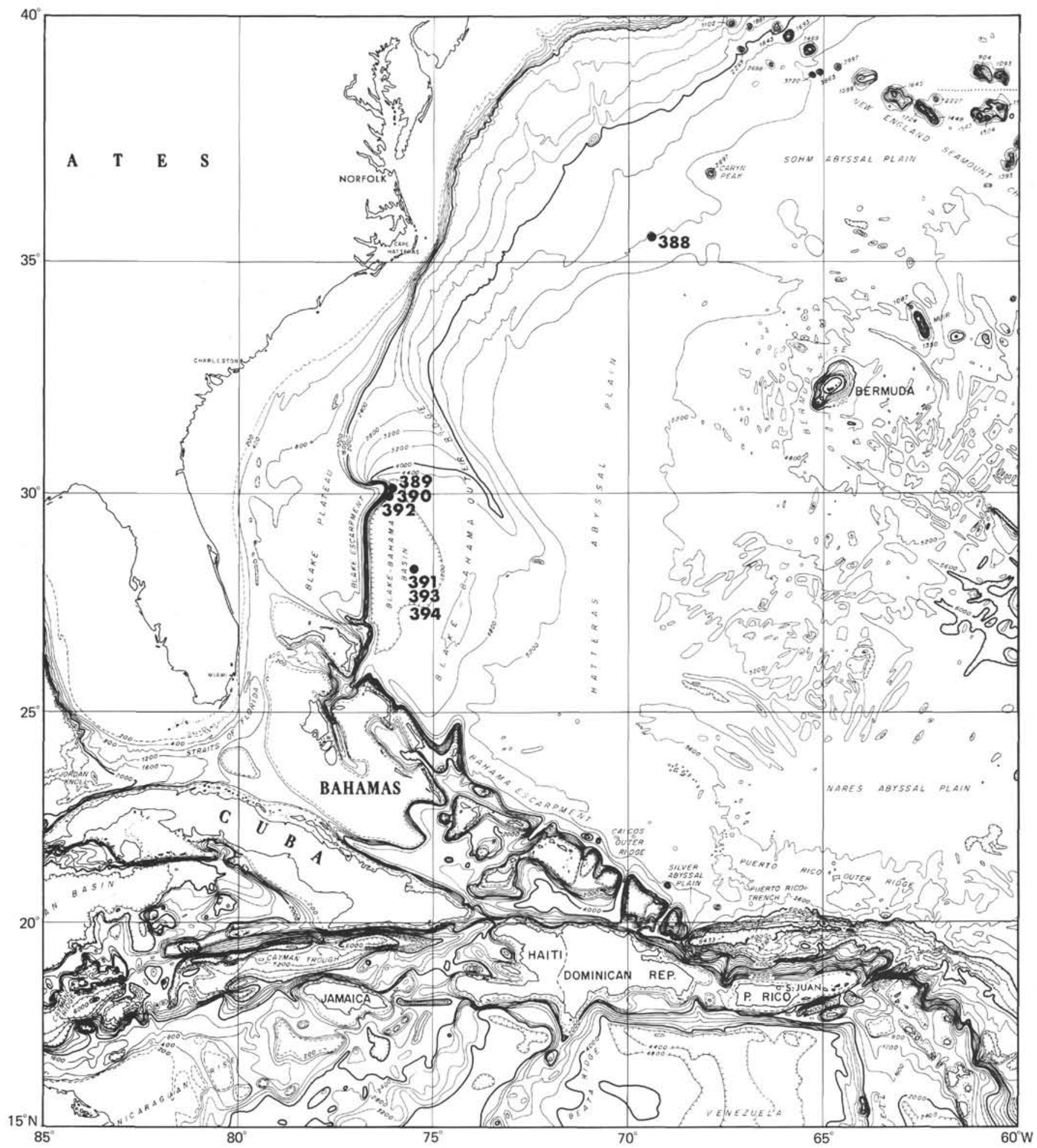

Figure 1. Location of Leg 44 drill sites.

factors. The neritic environment is often more variable and less predictable. Calcareous nannoplankton which can encyst or resort to benthic stages for part of their life cycle are generally more successful in unstable nearshore environments. Planktic organisms which respond rapidly to increased fertility are also more common in the nearshore environment. However, neritic forms are generally poorer age indicators because they rarely occur or are absent in the much more widespread oceanic deposits.

Calcareous nannoplankton assemblages in the sediments are greatly influenced by preservation. Dissolution at the sediment/water interface preferentially removes the more delicate forms (McIntyre and McIntyre, 1971; Roth and Berger, 1975). Diagenetic changes result in secondary cal- 
cite deposition on the larger crystallites of coccoliths and dissolution of coccoliths mostly composed of smaller crystallites (Adelseck et al., 1973; Roth et al., 1975). Thus, more deeply buried carbonates contain coccolith assemblages biased toward more robust groups of coccoliths.

Secondary calcite overgrowth begins in surface sediments (Roth and Berger, 1975), but increases drastically in pelagic carbonate sediments with more than 150 meters overburden (Roth and Thierstein, 1972). Increased clay content in hemipelagic deposits seems to retard diagenesis because of a reduction in permeability of the sediments. High organic matter content in anoxic sediments leads to increased production of $\mathrm{CO}_{2}$ by bacteria that disintegrate organic matter, lower the $p \mathrm{H}$, and therefore, increase dissolution. Thus, green and black clays generally contain highly dissolved coccolith assemblages. This is shown quite clearly by comparing the poorly preserved coccolith assemblages from Hole 391C where mid-Cretaceous sediments were deposited under anoxic conditions with the much more diverse and better preserved assemblages of the same age in Hole 390 which were deposited above the oxygen minimum layer.

When establishing a nannoplankton zonation, index species that fulfill the following requirements should be selected:

1) Species should be oceanic and their distribution controlled mostly by surface water temperature; not so much by fertility.

2) They should have a wide latitudinal distribution.

3) They should be resistant to preservational changes.

4) They should have short stratigraphic ranges.

5) They should be easy to recognize in order to avoid misidentifications.

Unfortunately, these criteria are only fulfilled by few groups of Cretaceous coccolithophores. In the Lower Cretaceous the placoliths (Watznaueria, Tubodiscus) and the genera Retecapsa, Cruciellipsis, Cretarhabdus, Podorhabdus, Parhabdolithus, and Lithraphidites fulfill criteria 1, 2, and 3; however, criteria 4 and 5 are not fulfilled for many of the species belonging to those genera. The nannoconids are relatively solution-resistant but they are neritic and not always easy to identify. The distribution of the genera Micrantholithus and Braarudosphaera is more controlled by their nearness to shore and perhaps fertility, than by temperature and stage of evolution; they are basically "facies fossils", like the nannoconids. Many mid-Cretaceous markers are not resistant to dissolution and diagenesis (e.g., Chiastozygus litterarius, to a lesser extent also Prediscosphaera cretacea). Others are presently fraught by taxonomic problems (Broinsonia, Gartnerago, Kamptnerius, etc.). In the Late Cretaceous (Campanian and Maestrichtian) more pronounced gradients in surface water temperatures (Douglas and Savin, 1976) lead to increased provinciality. Thierstein (1976) demonstrates that the first occurrence of the genera Kamptnerius and Lucinorhabdus is time-transgressive. The distribution of Tetralithus trifidus, T. gothicus, Lithraphidites quadratus, and $L$. praequadratus is also more latitudinally restricted than previously assumed. Worsley and Martini (1971) showed restricted latitudinal distribution for Micula mura and Nephrolithus frequens.

A compilation of nannoplankton zones, biohorizons, and absolute ages for important stages and zone boundaries is shown in Figure 2. I have drawn freely from publications of
Bukry and Bramlette (1970); Bukry (1973, 1975, 1976); Gartner (in Cita and Gartner, 1971); Manivit (1971); Perch-Nielsen (1968, 1969); Thierstein (1971, 1973, 1974, 1976); Verbeek (1976); Roth (1973); and Roth and Thierstein (1972). Some zonal definitions were changed as indicated by the footnotes on Figure 2 . The species used for the definition of zonal boundaries are shown under "biohorizons." I have introduced a numbering system as a shorthand notation for these zone names which are taken from long and cumbersome species names. No implication of finality is implied by this ordinal sequence. A comparison of the number of calcareous nannoplankton zones with the planktonic foraminifer zones listed in van Hinte (1976a) shows that there are 36 planktonic foraminifer/calpionellid zones for the Cretaceous versus 23 calcareous nannoplankton zones. Thus the former zonation has slightly better resolution. Calcareous nannoplankton, however, are slightly more likely to be incorporated into pelagic sedimentary record because they withstand greater diagenetic changes than do planktonic foraminifers (Schlanger et al., 1973). Most Lower Cretaceous sections recovered by deep-ocean drilling are dated on the basis of phytoplankton zonations. In the Upper Cretaceous, planktonic foraminifers - if well preserved - still provide more accurate biostratigraphic subdivisions.

Paleontologists can distinguish at least 13 calcareous nannoplankton zones for the last $30 \mathrm{~m}$.y. of the Cretaceous indicating a mean stratigraphic resolution of $2.3 \mathrm{~m} . \mathrm{y}$.

In the Aptian-Albian interval, lasting about $15 \mathrm{~m}$.y. five nannoplankton zones are recognized resulting in a mean resolution of $3 \mathrm{~m} . \mathrm{y}$. Lower Cretaceous (Barremian to Berriasian) nannoplankton zones represent an average of 4 $\mathrm{m} . \mathrm{y}$. or somewhat longer. The species diversity of calcareous nannoplankton is low in the Neocomian, increases rapidly in the mid-Cretaceous, and remains high throughout the Late Cretaceous (Roth, in press). Therefore, much better stratigraphic resolution is possible in the Middle and Late Cretaceous. Also, diagenetic alterations are generally more severe in Lower Cretaceous limestone sequences than in marl and chalk of the Middle to Upper Cretaceous; thus, a preservational bias tends to amplify primary differences in diversity. The stratigraphic distribution of many Cretaceous nannoplankton species is still poorly known. We are even more ignorant about ecological control of Cretaceous coccolith distribution. Thus, Cretaceous nannoplankton biostratigraphy is in a stage of "youthful growth" and will not be stabilized for years to come.

\section{BIOSTRATIGRAPHIC EXTENT OF EUROPEAN CRETACEOUS STAGES AND NEWLY PROPOSED JURASSIC TO CRETACEOUS OCEANIC STAGES}

Stratotype sections for Cretaceous stages have been largely selected in regions of strong tectonic activities like the rapidly subsiding marginal basins of southeastern France, or in epicontinental seas where synsedimentary erosion destroyed part of the record. The facies in the stratotype sections are mostly unsuitable for the occurrence or preservation of rich planktonic foraminifer and coccolith assemblages as shown by Thierstein $(1971,1973)$ and Manivit (1971). The presently available microplankton zona- 


\begin{tabular}{|c|c|c|c|c|c|c|c|c|c|c|}
\hline \multirow{2}{*}{$\begin{array}{c}\text { European } \\
\text { Stages }\end{array}$} & \multirow{2}{*}{$\begin{array}{l}\text { Oceanic } \\
\text { Stages }\end{array}$} & \multirow{2}{*}{$\begin{array}{l}\overline{\grave{B}} \\
\frac{\bar{E}}{8} \\
\frac{9}{8}\end{array}$} & \multirow{2}{*}{\multicolumn{2}{|c|}{$\begin{array}{c}\text { Calcareous } \\
\text { Nannoplankton } \\
\text { Zones }\end{array}$}} & & \multirow{2}{*}{$\begin{array}{l}\text { Important Nannoplankton } \\
\text { Biostratigraphic Horizons }\end{array}$} & \multicolumn{3}{|c|}{$\begin{array}{l}\text { Zonal Assignments } \\
\text { Leg } 44\end{array}$} & \multirow{2}{*}{ 岕 } \\
\hline & & & & & & & $\begin{array}{l}\text { Hole } \\
390\end{array}$ & $\begin{array}{l}\text { Hole } \\
390 \mathrm{~A}\end{array}$ & $\begin{array}{l}\text { Hole } \\
391 \mathrm{C}\end{array}$ & \\
\hline Danian & Shatskyan & \multirow{4}{*}{65} & \multicolumn{2}{|c|}{ Markalius astroporus } & NP1 & Cretaceous nannofiora & & & & NP1 \\
\hline \multirow{3}{*}{ 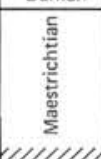 } & \multirow{6}{*}{ Bermudan } & & \multicolumn{2}{|c|}{ Micula mura/Nephrolithus frequens } & NC 23 & S Micula mura & & & & $\mathrm{NC23}$ \\
\hline & & & \multicolumn{2}{|c|}{ Lithraphidites quadratus } & NC 22 & $\begin{array}{l}\text { Nephrolithus frequens } \\
\text { Lithraphidites quadratus s. str. }\end{array}$ & & $\begin{array}{l}12-1 \text { to } \\
13-1\end{array}$ & & NC22 \\
\hline & & & \multicolumn{2}{|c|}{$\begin{array}{l}\text { Lithraphidites } \\
\text { praequadratus (a) }\end{array}$} & NC 21 & Lithraphidites praequadratus & & $\begin{array}{l}13.2 \text { to } \\
14.5\end{array}$ & & \\
\hline \multirow{3}{*}{ 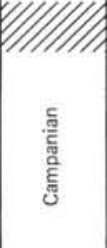 } & & $70-$ & \multicolumn{2}{|c|}{ Tetralithus trifidus } & NC 20 & Tetralithus murus & & $? 14, \mathrm{CC}$ & & NC20 \\
\hline & & $75-$ & \multicolumn{2}{|c|}{ Tetralithus aculeus } & NC 19 & & & & & \\
\hline & & \multirow[b]{2}{*}{$80-$} & \multicolumn{2}{|c|}{ Broinsonia parca } & NC 18 & & & & & \\
\hline UIIIIIII & \multirow{4}{*}{ 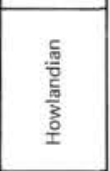 } & & \multicolumn{2}{|c|}{ Tetralithus obscurus. } & $N C 17$ & —_ Broinsonia parca & & & & \\
\hline ?Santonian & & & Micula conca & & Ne Th & $-\left\{\begin{array}{l}\text { Tetraflithus obscurus } \\
\text { Micula concava }\end{array}\right.$ & & & & \\
\hline (VIIIIIII & & \multirow[b]{2}{*}{$85-$} & \multicolumn{2}{|c|}{ Broinsonia lacunosa } & NC 16 & $\begin{array}{l}\text { Lithraphidites helicoidens } \\
\text { Broinsonia lacunosa }\end{array}$ & & & & \\
\hline Coniacian & & & \multicolumn{2}{|c|}{ Marthasterites furcatus } & NC 15 & $\int$ Marthasterites furcatus & & & & \\
\hline \multirow{2}{*}{ Turonian } & \multirow{2}{*}{$\begin{array}{l}\text { Natura- } \\
\text { listian }\end{array}$} & & \multicolumn{2}{|c|}{ Kamptnerius magnificus } & NC 14 & Liffellithus eximius & & & & \\
\hline & & & Micula staur & & NC 13 & Micula staurophora & & & & \\
\hline EIIIIIIIs & Tene- & $90-1$ & Gartrierago o & uum & NC 12 & 1 Tetralithus oyramidus & & & & \\
\hline Cenom. & mán & & Lithraphidite & utum & NC 11 & Lithraphidites acutum & & & & \\
\hline Albian & Argusian & & $\begin{array}{l}\text { Eiffellitus } \\
\text { turriseiffeli }\end{array}$ & & NC 10 & & & & & \\
\hline & & & Axipodorhat & albianus & NC 9 & $\begin{array}{l}\text { Eiffellithus turriseiffeli } \\
\text { Axipodorhabdus albianus }\end{array}$ & $3-1$ & & & NC9 \\
\hline & 琧 & & Prediscospha & cretacea & NC 8 & Prediscosohaera cretacea & $\begin{array}{l}3.2, \\
3.3\end{array}$ & & $79 \cdot 2$ & NC8 \\
\hline Aptian & $\begin{array}{l}\overline{\overline{\mathrm{w}}} \\
\stackrel{\mathrm{d}}{\mathrm{D}} \\
\end{array}$ & & Parhabdolith & ngustus & NC 7 & & $\begin{array}{l}4.2 \text { to } \\
5 \cdot 1\end{array}$ & & $\begin{array}{l}111-1 \\
\text { to } \\
15-2\end{array}$ & NC7 \\
\hline 8111111 & & & Chiastozygus & erarius. & NC 6 & Parhabdolithus angustus & & & $15-3$ & NC6 \\
\hline קות & 喜 & 100 & Watznaueria & $\begin{array}{l}\text { Micrantholithus } \\
\text { obtusus }\end{array}$ & NC $5 b$ & 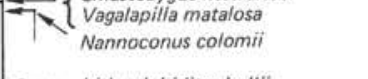 & & & $16-1$ & NC5 \\
\hline Barremian & 胥 & & (NC 5) & $\begin{array}{l}\text { Nannoconus } \\
\text { bucheri (a) }\end{array}$ & NC 5a & $\neg$ Lithradphidites bollit & & & $\begin{array}{l}\text { to } \\
16-4\end{array}$ & \\
\hline 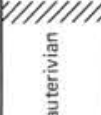 & Merrittian & $120-$ & $\begin{array}{l}\text { Cruciellpsis } \\
\text { cuvillieri } \\
\text { (NC 4) }\end{array}$ & $\begin{array}{l}\text { Lithraphidites } \\
\text { boillii (b) }\end{array}$ & NC 4b & Lithraphidites bollii & & & $\begin{array}{l}17.1 \\
\text { to }\end{array}$ & NC4 \\
\hline$\stackrel{\pi}{I}$ & & & & $\begin{array}{l}\text { Calcicalathina } \\
\text { oblongata }\end{array}$ & NC 4a & & & & $24-1$ & \\
\hline 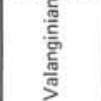 & & $125-$ & $\begin{array}{l}\text { Tubodiscus v } \\
\text { Diadorhomb }\end{array}$ & & NC 3 & Tubodiscus verenae & & & $\begin{array}{l}24-2 \\
\text { to } \\
31-5\end{array}$ & NC3 \\
\hline WIIIIIII & Abacoan & $130-$ & Retecapsa ne & miana (a) & NC 2 & $\begin{array}{l}\text { Celecapsa angustiforata } \\
\text { Retcicalathina elongata }\end{array}$ & & & $\begin{array}{l}31-6 \\
\text { to }\end{array}$ & NC2 \\
\hline & & & & & & $\begin{array}{l}\text { Cruciellipis cuvillieri s. str. } \\
\text { Retecapsa neocomiana }\end{array}$ & & & & \\
\hline Berriasian & Carynian & $135-$ & $\begin{array}{l}\text { Nannoconus } \\
\text { Lithraphidit }\end{array}$ & Imiiolensis & NC 1 & $\int$ Nannoconus colomii & & & $\begin{array}{l}42.5 \\
\text { to } \\
44.6 \text { (c) }\end{array}$ & NC1 \\
\hline & Salvadorian & & Conusphaera & xicana & Jurassic & $\begin{array}{l}\text { L Lithraphidites carniolensis } \\
\text { Conusphaera mexicana }\end{array}$ & & & & \\
\hline
\end{tabular}

Footnotes: Zonation based on the latest available compilations by Bukry (1975), Hill (1976), Roth (1973).

Thierstein $(1973,1974,1976$, in press) and Verbeek (1976)

(a) New zone defined in this paper

(b) Zonal boundary definitions modified in this paper

(c) Lowest sample studied, see Wird (this volume) for basal Cretaceous-Upper Jurassic part of the section

Figure 2. Correlation of nannoplankton zones, biostratigraphic horizons and absolute ages. 
tions are more refined and have a much more global applicability to the geochronological units than those previously defined. Thus, zonations on the basis of planktonic forms seem to make a better standard of reference for world-wide marine Cretaceous stratigraphy than a system of land-based stages. If chronostratigraphic units defined on the basis of stratotypes are used for world-wide correlations, any ambiguities in the biostratigraphic extent of classical stages or errors in the definition of boundaries are automatically introduced into stratigraphic correlations. Thus, it seems more important to determine the absolute "ages" of biostratigraphic horizons - zonal boundaries or "datum levels" - than to "translate", biostratigraphic units into stages, correlate the stages with radiometric dates or magnetic reversals. However, because the classical stages are so familiar to most geologists I present a correlation of nannoplankton zones with classical stages in Figure 2. These correlations are somewhat arbitrary as only some of the Cretaceous stratotypes and parastratotypes contain nannoplankton or microzoo-plankton preserved and described well enough to allow recognition of nannoplankton or planktonic foraminifer zones (Manivit, 1971; Thierstein, 1971, 1973; Verbeek, 1976). Thus, uncertainties in the relationship of European stage boundaries and nannoplankton zones are indicated by a hatchure pattern on Figures 2 and 3 .

We must establish a composite biostratigraphic standard which would allow us to find the correct sequence of paleontological events (highest occurrence surfaces = HOS, lowest occurrence surfaces $=$ LOS, and acmes) of major planktonic, benthic, and nektonic fossil groups. Much work needs to be done to achieve consistent results. Mathematical correlation methods, such as the ones proposed by Hay (1972) and Shuey et al. (1977), should aid in this process. Because so many biostratigraphic advances have been made during the study of oceanic sections which often contain very well preserved and rich oceanic fossil assemblages, I follow Bukry (1973) and extend his oceanic chronostratigraphy work back into the Cretaceous and uppermost Jurassic to provide a chronostratigraphic framework for oceanic stratigraphy. A single stratotype section is defined in a particular hole drilled by the Deep Sea Drilling Project. Cores recovered from this hole are deposited at the DSDP East and West Coast Repositories and are thus accessible to the scientific investigators. In two cases, boundary stratotypes are defined because the sections were not cored discontinuously or were not completely recovered. Future drilling may provide better sections which could then be substituted. Additional reference sections which may be of a different facies (e.g., chalks and limestones instead of sapropellites) are also given. Naming the oceanic stages is problematic because named permanent features are lacking. I have chosen geographic features above sea level located near the stratotype section or large, well-defined submarine topographic features (Seamounts and Submarine Plateaus).

All boundary definitions are made on the basis of biostratigraphic events. Lithology and fossil groups described from the stratotype are listed. An attempt is made to correlate important magnetostratigraphic events with the oceanic stages (Figure 3 ). The number of more or less accurately dated magnetic anomalies is still limited. The oldest sediment of Site 105 is Oxfordian in age (fide Thierstein, 1976);
Site 105 is located between anomalies M24 and M25 (Larson and Hilde, 1975). Site 307 located on magnetic anomaly M21 is difficult to date accurately owing to poor calcareous and siliceous fossil assemblages. The coccolith assemblages may be Salvadorian because they lack typical Lower Cretaceous markers. The next higher anomaly that can be "dated" at the present time is M9 which is of Merrittian or possibly late Abacoan age (it contains Cruciellipsis cuvillieri, and Tubodiscus verenae). Site 166 lies between anomalies M7 and M8, and it is Canaveralian in age (NC5 to NC6). The assemblages in the basal sediments of Site 303 which is located on magnetic anomaly M4 are too poor to allow a very accurate age determination. A Canaveralian age seems most probable because anomaly M7 cannot be older than Canaveralian (because of the lack of Cruciellipsis cuvillieri in basal sediments at Site 166). Other correlations of oceanic stages and magnetic reversals are more tenuous since they are based on the assumption that spreading rates were constant between the time of formation of sea floor containing anomalies M25 and M7.

Radiometric ages of important biostratigraphic and chronostratigraphic boundaries are discussed in the paragraphs following the definition of oceanic stages which are given below.

\section{Catgapian Stage}

Base: LOS Stephanolithion bigotii.

Top: LOS Conusphaera mexicana.

Boundary stratotype of base: DSDP Site $100,24^{\circ} 41^{\prime} \mathrm{N}$, $73^{\circ} 48^{\prime} \mathrm{W}$, water depth 5325 meters, Core 3,250 meters below sea floor, after Thierstein (1976).

Boundary stratotype of top: DSDP Site $105,34^{\circ} 54^{\prime} \mathrm{N}$, $69^{\circ} 109^{\prime} \mathrm{W}$, water depth 5251 meters, between Cores 34 and 35,576 meters below sea floor.

Lithology: Red and gray-green limestones.

Fossil groups present: Calcareous nannofossils, palynomorphs, benthic foraminifers, calpionellids, Globigerina ?, ostracodes, aptychi.

Age: 143 m.y.-141 m.y.

Magnetic anomalies: M22-M23.

Correlation with land record: Upper Oxfordian to Kimmeridgian.

Derivation of name: After Cat Gap, near the DSDP Sites 100 and 99.

Remarks: The markers used for the boundary definition are easily recognized. This stage marks the transition phase from rich Oxfordian assemblages to the ones with nannoconids.

\section{Salvadorian Stage}

Base: LOS Conusphaera mexicana.

Top: LOS Nannoconus colomii.

Type section: DSDP Site 105, Cores 34 to 33, 576 meters to 560 meters below sea floor.

Lithology: Red and green clayey limestones.

Fossil groups present: Calcareous nannofossils, aptychi, benthic foraminifers, ostracodes.

Age: 141 m.y.-136 m.y.

Magnetic anomalies: M20-M21, ? M22.

Correlation with stages on land: Tithonian.

Derivation of Name: After nearby San Salvador Island. 
P. H. ROTH

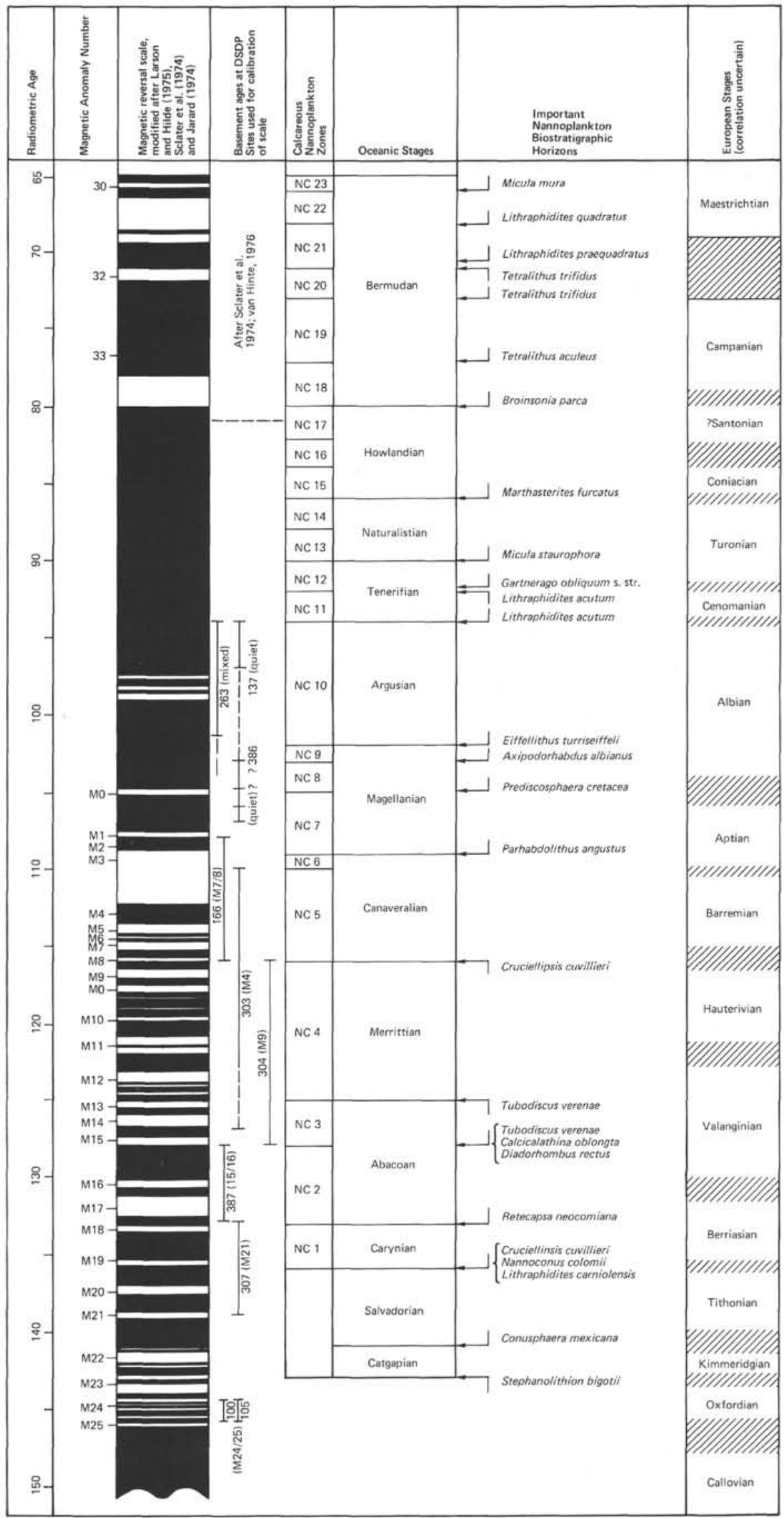

Figure 3. Correlation of magnetostratigraphic events, oceanic and European stages. 


\section{Carynian Stage}

Base: LOS Lithraphidites carniolensis and LOS Nannoconus colomii.

Top: LOS Retecapsa neocomiana.

Type section: DSDP Site 105, 559 meters below sea floor to 515 meters below sea floor.

Lithology: White and gray pelagic limestone.

Fossil groups present: Calcareous nannoplankton, benthic foraminifers, acritarchs, aptychi, calpionellids.

Derivation of name: After nearby Caryn Seamount.

Age: 136 m.y.-133 m.y.

Magnetic anomalies: M18-20.

Correlation with land record: Lower Berriasian.

\section{Abacoan Stage}

Base: LOS Retecapsa neocomiana.

Top: HOS Tubodiscus verenae (close to HOS Diadorhombus rectus).

Type section: DSDP Hole $391 \mathrm{C}, 28^{\circ} 13.7^{\prime} \mathrm{N}, 75^{\circ} 37^{\prime} \mathrm{W}$, water depth 4963 meters, Cores 42 to 24,1300 meters to 1125 meters below sea floor.

Lithology: Gray bioturbated and laminated calcilutites, some dark shales.

Fossil groups present: Calcareous nannoplankton, radiolarians, calpionellids, rare benthic foraminifers, aptychi.

Derivation of name: From Great Abaco, Bahamian Islands.

Age: 133 m.y.-124 m.y.

Magnetic anomalies: M13-M17.

Correlation with land record: Upper Berriasian to upper Valanginian.

Remarks: Stratotype sections for the Berriasian, Valanginian, and Hauterivian contain only poor assemblages of nannofossils and are thus unsuitable as a standard reference (Thierstein, 1973).

\section{Merrittian Stage}

Base: HOS Tubodiscus verenae. (Close to HOS Diadorhombus rectus).

Top: HOS Cruciellipsis cuvillieri.

Type section: DSDP Hole 391C, Cores 31 to 17,1300 meters to 1030 meters below sea floor.

Lithology: White and gray pelagic limestones.

Fossil groups present: Calcareous nannofossils, benthic foraminifers, palynomorphs.

Derivation of name: After Merritt Island, east coast of Florida, due west of Site 391C, type locality for this stage.

Age: 124 m.y.-116 m.y.

Magnetic anomalies: M8-M12.

Correlation with land record: Upper Valanginianmid-Hauterivian.

Remarks: Cruciellipsis cuvillieri is one of the most easily recognizable and robust calcareous nannoplankton species and can be identified in sections with diagenetic changes. The base of this stage is somewhat more difficult to recognize in poorly preserved samples. Thus two marker species are given to facilitate recognition of this boundary.

\section{Canaveralian}

Base: HOS Cruciellipsis cuvillieri.
Top: LOS Parhabdolithus angustus.

Type section: DSDP Hole 391C, Cores 15 to 16,1130 meters to 1000 meters below sea floor.

Additional section: DSDP Site 105, Cores 22 to 16 .

Lithology: Pelagic limestones, calciturbidites.

Fossil groups: Calcareous nannoplankton, benthic foraminifers, palynomorphs, aptychi, radiolarians.

Derivation of name: After Cape Canaveral which is due west of Sites 105 and 391 which contain the best sections recovered so far.

Age: 116 m.y.-109 m.y.

Magnetic anomalies: M4-M7.

Correlation with stages on land: Uppermost Hauterivian-Barremian.

Remarks: The stratotype section of the Barremian is composed mostly of limestone; calcareous nannoplankton assemblages are poor according to Thierstein (1973). Thus the Canaveralian is a better standard of reference.

\section{Magellanian Stage}

Base: LOS Parhabdolithus angustus.

Top: LOS Eiffellithus turriseiffeli.

Type section: DSDP Site $167,07^{\circ} 04^{\prime} \mathrm{N}, 27^{\circ} 03.6^{\prime} \mathrm{W}$, water depth 3176 meters, Cores 70 to 64,944 meters to 880 meters below sea floor.

Atlantic reference sections: Hole 391C, Cores 10 to 15. Site 105 , also contains a good reference section (Cores 13 to 11, according to Wilcoxon, 1972.)

Lithology (type section): Pelagic limestones and chalks.

Fossil groups present: Calcareous nannofossils, benthic foraminifers, palynomorphs (Atlantic sections only).

Age: 109 m.y.-102 m.y.

Magnetic anomalies: M0-M3.

Correlation with land record: Aptian to lower Albian.

Remarks: In the Atlantic Magellanian sediments deposited under oxidizing conditions occur only at sites in shallow water. Deeper sites are characterized by mostly sapropellites, which often lack calcareous plankton at the top. Therefore, I selected a type section from the Pacific for this stage. Aptian stratotypes contain poor coccolith assemblages. Albian stratotypes are discontinuous and nannofossils are moderately well to poorly preserved (Thierstein, 1973; Manivit, 1971).

\section{Argusian Stage}

Base: LOS Eiffellithus turriseiffeli.

Top: LOS Lithraphidites acutum (close to HOS Planomalina buxtorfi).

Type section: DSDP Site $386,31^{\circ} 11^{\prime} \mathrm{N}, 64^{\circ} 15^{\prime} \mathrm{W}$, water depth 4783 meters, Cores 55 to 49 (according to H. R. Thierstein, personal communication, 1977).

Pacific reference section: DSDP Site 167, Cores 62-67, 910 meters to 870 meters below sea floor.

Fossil groups present: Calcareous nannoplankton, benthic and planktonic foraminifers, palynomorphs.

Lithology: Black to green-gray claystones and marls in the type section; chalks with cherts in the Pacific reference section.

Age: 102 m.y.-94 m.y.

Magnetic anomalies: Mostly normal, mixed polarities observed in sedimentary section recovered at Site 263, Indian Ocean (Jarrard, 1974). 
Correlation with land record: Upper Albian -(?) lower Cenomanian.

Derivation of name: After the small Argus Island, about 30 miles southwest of Bermuda.

Remarks: The Argusian consists mostly of sapropellites over much of the Atlantic and Indian oceans. Pelagic sediments deposited under oxidizing conditions (chalks, cherts, limestones) occur only in the Pacific Ocean. Etching may have reduced the diversity of nannoplankton assemblages in sapropellites. Overgrowths are common in the Pacific chalks. Correlation of the Argusian with the land record is difficult because the lower boundary of the Cenomanian has not yet been defined on the basis of planktonic nannofossils or microfossils.

\section{Tenerifian Stage}

Base: LOS Lithraphidites acutum (HOS Planomalina buxtorfi closely approximates this level).

Top: LOS Micula staurophora.

Type section: DSDP Site $137,25^{\circ} 56^{\prime} \mathrm{N}, 27^{\circ} 04^{\prime} \mathrm{N}$ water depth 5361 meters, Cores 16 to 7,36 meters to 257 meters below sea floor.

Boundary stratotype for top: Site $258,33^{\circ} 48^{\prime}$, $112^{\circ} 29^{\prime}$, water depth 2793 meters, Naturalist Plateau, Indian Ocean, Core 13, 259 meters below sea floor.

Boundary stratotype for base: DSDP Site 137, Core 16, Section 1, 376 meters below sea floor.

Lithology of type section of stage: Marl with abundant and well preserved calcareous micro- and nannoplankton. Similar lithologies occur in the boundary stratotype on the Naturalist Plateau.

Fossil groups present: Calcareous nannoplankton and planktonic foraminifers are common and well preserved; radiolarians and a few benthic foraminifers are present.

Magnetic anomalies: Quiet zone.

Correlation with land record: Cenomanian to lower Turonian.

Derivation of name: From Tenerife, a town on the Canary Islands which are in the vicinity of Site 137.

Remarks: Coring at Site 137 recovered an excellent continuous section of Tenerifian with very well preserved calcareous nannoplankton and planktonic foraminifers (Roth and Thierstein, 1972; Beckmann, 1972). However, the top of this stage is missing at DSDP Site 137. Therefore, a boundary stratotype is defined at DSDP Site 258. Manivit et al. (1977) indicated that Lithraphidites alatus first occurs in the middle Albian. They described the new species Lithraphidites acutum (a form with pointed extensions included in $L$. alatus by Thierstein, 1974) from Cenomanian sediments. The two forms occur together in deep sea sediments considered to be Cenomanian in age. However, I prefer to use Lithraphidites acutum Verbeek and Manivit as marker for this stage boundary.

\section{Naturalistian Stage}

Base: LOS Micula staurophora.

Top: LOS Marthasterites furcatus.

Type section: DSDP Site 258, Core 13 , Section 4 to Core 11, Section 2, 258 meters to 217 meters below sea floor.
Lithology: Nannoplankton chalk.

Fossil groups present: Calcareous nannoplankton, planktonic foraminifers, radiolarians.

Derivation of name: After Naturalist Plateau, Indian Ocean, southeast of Perth, Australia.

Age: 90 m.y. -86 m.y.

Correlation with land record: Middle to upper Turonian.

Remarks: Both markers used for the boundary are easy to recognize and well defined. Site 258 contains a continuous section with both calcareous planktonic groups well represented; the preservation of planktonic foraminifers is not as good as the preservation of coccoliths. Nannoplankton indicate a transitional to cool depositional environment.

\section{Howlandian Stage}

Base: LOS Marthasterites furcatus.

Top: LOS Broinsonia parca.

Type section: DSDP Site 167, Magellan Rise, Cores 59 to 51,841 meters to 777 meters below sea floor.

Lithology: Pelagic deep-sea carbonates and cherts.

Fossils present: Nannofossils, planktonic foraminifers, radiolarians.

Age: 80 m.y.-86 m.y.

Correlation with land record: Coniacian to Santonian.

Derivation of names: After Howland Island, about 360 miles south of DSDP Site 167.

Remarks: A good high-latitude section of lower Howlandian sediments was recovered at Site 258, Naturalist Plateau, Indian Ocean.

\section{Bermudan Stage}

Base: LOS Broinsonia parca.

Top: HOS Cretaceous nannofossils.

Remarks: Bukry (1973) defined this stage.

\section{DETERMINATION OF RADIOMETRIC AGES FOR IMPORTANT CRETACEOUS STRATIGRAPHIC UNITS}

The most recent time scale for the late Mesozoic published after the compilation of Lambert (1973), is the one by van Hinte (1976a, b). He demonstrates that the Cretaceous time scale is still in a state of flux, especially for the time interval from $135 \mathrm{~m}$.y. to $90 \mathrm{~m} . \mathrm{y}$. The boundary between the Lower and Upper Cretaceous seems to be the least stable; radiometric ages range from $93 \mathrm{~m} . \mathrm{y}$. to $110 \mathrm{~m} . \mathrm{y}$. (van Hinte, 1976a, fig. 1). More than half the radiometric ages are made on the basis of ${ }^{40} \mathrm{~K} /{ }^{40} \mathrm{Ar}$ determinations in glauconites which are very susceptible to argon losses. This results in ages which are too "young." Errors of 10-20 per cent in age are not uncommon (Fauvre and Powell, 1972). Reworked glauconites are often found in lag deposits and just above sedimentary breaks. Ages determined from reworked glauconites would be too "old.'" Therefore, I did not accept ages which were too far removed from the main clusters of age determinations. Ages determined from volcanic or plutonic minerals (K-feldspars, biotites) are more reliable but very few are available for the Cretaceous. I chose a short Cenomanian and thus fixed the Cenomanian/Albian bound- 
ary at 95 m.y. following Lambert (1973) and Obradovich and Cobban (1975). The dearth of Cenomanian and Barremian sediments in the pelagic realm of the Pacific and the Western North Atlantic would indicate that these time periods were either of short duration, a more likely assumption, or that major oceanographic changes lead to reduced productivity or increased dissolution or submarine erosion by currents.

To allow a comparison of the time scales proposed by van Hinte (1976a) and the one used in this paper, I calculated sediment accumulation rates using the two scales for selected Pacific and Atlantic Lower to Mid-Cretaceous sections (Table 1). In all three sites where stratigraphic control was sufficient (Sites 167, 105 and 391) sedimentation rates below the Cruciellipsis cuvillieri HOS are increased by almost a factor of two if van Hinte's time scale is usedaccumulation resulting in unusually high sediment rates for compacted pelagic limestones. Therefore, I prefer the time scale given in Table 1, at least for now. Correlations of the oceanic and land-based stages with the magnetostratigraphic units (Larson and Pitmann, 1972; Larson and Hilde, 1975; Sclater et al., 1974) and the preferred radiometric age scale for the Mesozoic are shown in Figure 3.

\section{PRESERVATION OF CALCAREOUS NANNOFOSSILS}

The two processes that most strongly alter the composition of calcareous nannoplankton sediment assemblages are dissolution and diagenesis. Dissolution takes place mostly at the sediment/water interface, probably somewhat aided by burrowers which keep bringing buried sediments back to the sea surface where they are exposed to aggressive bottom waters. Once sediments are buried, dissolution does not stop. Bacterial disintegration of organic matter can contribute $\mathrm{CO}_{2}$ to the interstitial waters resulting in dissolution of

TABLE 1

Sediment Accumulation Rates in Meters per Million Years for Selected Lower to Middle Cretaceous Deep Sea Drilling Sites Using the Time Scales of Roth, This Paper, and van Hinte, 1976

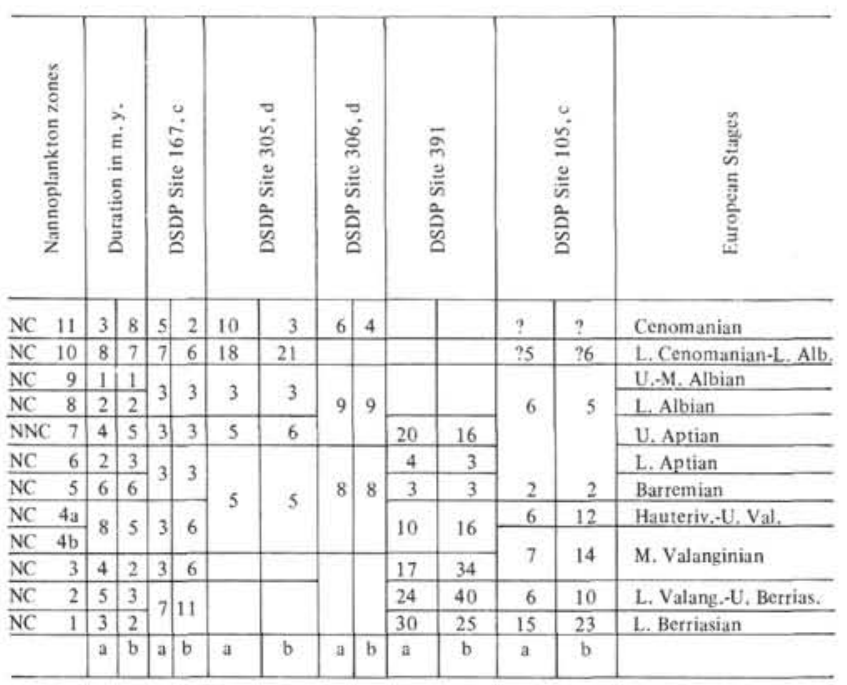

Footnotes: ausing time scale proposed in this paper

busing time scale of van Hinte (1976)

cbiostratigraphy after Roth (1973)

d biostratigraphy after Bukry (1975)

ebiostratigraphy after Thierstein (1976) calcium carbonate. A minor amount of secondary calcite overgrowth on placoliths can occur in sediments close to the sediment-water interface (Roth and Berger, 1975). After carbonates have been buried under several tens to about 200 meters of sediments, diagenesis intensifies. Smaller and more delicately constructed coccoliths are dissolved and secondary calcite overgrowths are deposited on larger crystallites (see Adelseck et al., 1973, for experimental confirmation of this process).

Most samples investigated show signs of both dissolution and secondary calcite overgrowths. I use a simple preservation scale modified after that of Roth and Thierstein (1972). None of the samples studied were pristine. The following criteria were used to assign preservation values to the samples:

\section{Etching}

E-1: Slightly jagged outlines of more delicate forms, delicate central structures damaged in some but not in all specimens.

E-2: More jagged outlines; delicate central structures frequently affected, more delicate forms slightly fragmented.

E-3: Only the more robust forms are preserved. Dominant genera, because of their resistance to dissolution, are the following: Watznaueria, Cyclagelosphaera, Retecapsa, Cretarhabdus, Cruciellipsis, Manivitella, Lithastrinus, and Eiffellithus.

E-4: Only fragments of coccoliths preserved; impossible to identify fragments to genus level.

\section{Overgrowth}

O-1: Slight overgrowth on central area structures and shield elements.

O-2: Increased overgrowth; some of the more delicate forms become sufficiently masked by secondary calcite to make identification difficult.

O-3: Only the most robust forms are preserved. Reduced diversity due to removal of delicate forms.

O-4: Complete recrystallization; coccoliths no longer identifiable to genus.

\section{DESCRIPTION OF CALCAREOUS NANNOPLANKTON AT SITES 390 AND 391}

\section{Site 390 (lat $30^{\circ} 08.54^{\prime} \mathrm{N}$, long $76^{\circ} 06.74^{\prime} \mathrm{W}$, water depth $2670 \mathrm{~m}$ )}

This site is located on the Blake Nose. Cores were recovered from 140 meters of Cenozoic to Magellanian calcareous ooze with varying amounts of siliceous planktonic skeletons, zeolites, and clays. This pelagic ooze rests on a Lower Cretaceous and older shallow-water limestone (wackestone). Upper Bermudan ooze is disconformably overlain by Shatskyan carbonate and rests on Magellanian calcareous ooze. Note that the Cretaceous pelagites at this site were deposited mostly under oxidizing conditions, in contrast to the mid-Cretaceous beds at the deeper Site 391 where most of the sediments show clear signs of anoxic sedimentation such as black shale and iron sulfides. The nannofossil assemblages in the oxidized 
sediments at Site 390 are generally richer and better preserved than in the mid-Cretaceous sediments at the deeper Site 391.

\section{Middle Maestrichtian assemblages: evolution of the Lithraphidites carniolensis-praequadratus- L. quadratus plexus}

The assemblages recovered in Cores 12 through 14 are rich, diversified, and have a neritic component: large specimens of Arkhangelskiella cymbiformis, Lithraphidites quadratus, Tetralithus aculeus, Cyclagelosphaera bergeri n. sp. (one of the species which cross the Cretaceous/ Tertiary boundary), Rheinhardites anthophorus, common large Microrhabdulus stradneri, and rare Braarudosphaera. Figure 4 shows age assignments for the samples studied, important marker species and a proposed zonation for this Maestrichtian section. The evolutionary lineage from Lithraphidites carniolensis to $L$. praequadratus and finally to $L$. quadratus can be used to refine upper Bermudan nannoplankton zonation, at least at mid to high latitudes (see Figure 4). A rapid change from the tapered fusiform Lithraphidites carniolensis with a length to total width ratio (L/W) of 5.0 or more to $L$. praequadratus with a $\mathrm{L} / \mathrm{W}$ ratio between 4.9 and 3.6 and at least one tapered end occurs in the lower part of Core 13. The width of $L$. praequadratus increases quite rapidly in the upper part of Core 13 until the typical $L$. quadratus stage, with a L/W ratio of 3.5 or less and truncated blades is reached.

Tetralithus trifidus is not found in the lowermost Maestrichtian at this site. At low latitudes it ranges as high as the LOS of Lithraphidites quadratus. Many of the latest Cretaceous coccolith species show a latitudinally controlled distribution. Nephrolithus frequens and Lithraphidites quadratus are missing from tropical open-ocean sites; Micula mura, Tetralithus trifidus, and $T$. gothicus are mid to low latitude forms. Increased temperature gradients between low and high latitudes, as shown by oxygen isotope determinations summarized by Savin (1977), were responsible for increased provinciality among calcareous nannoplankton.

We suspect that biohorizons recognized on the basis of these temperature-sensitive coccolith species (Micula mura [warm], Nephrolithus frequens [cold], Tetralithus gothicus [warm], T. trifidus [warm], Lithraphidites quadratus [cold], L. praequadratus [cold], Kamptnerius [cold]) are slightly time transgressive. Nevertheless, they form fairly reliable correlation surfaces if used in conjunction with other species.

Core 12 contains a rich assemblage with Arkhangelski cymbiformis, Watznaueria barnesae, and Lithraphidites quadratus. Transitional forms from Micula staurophora to

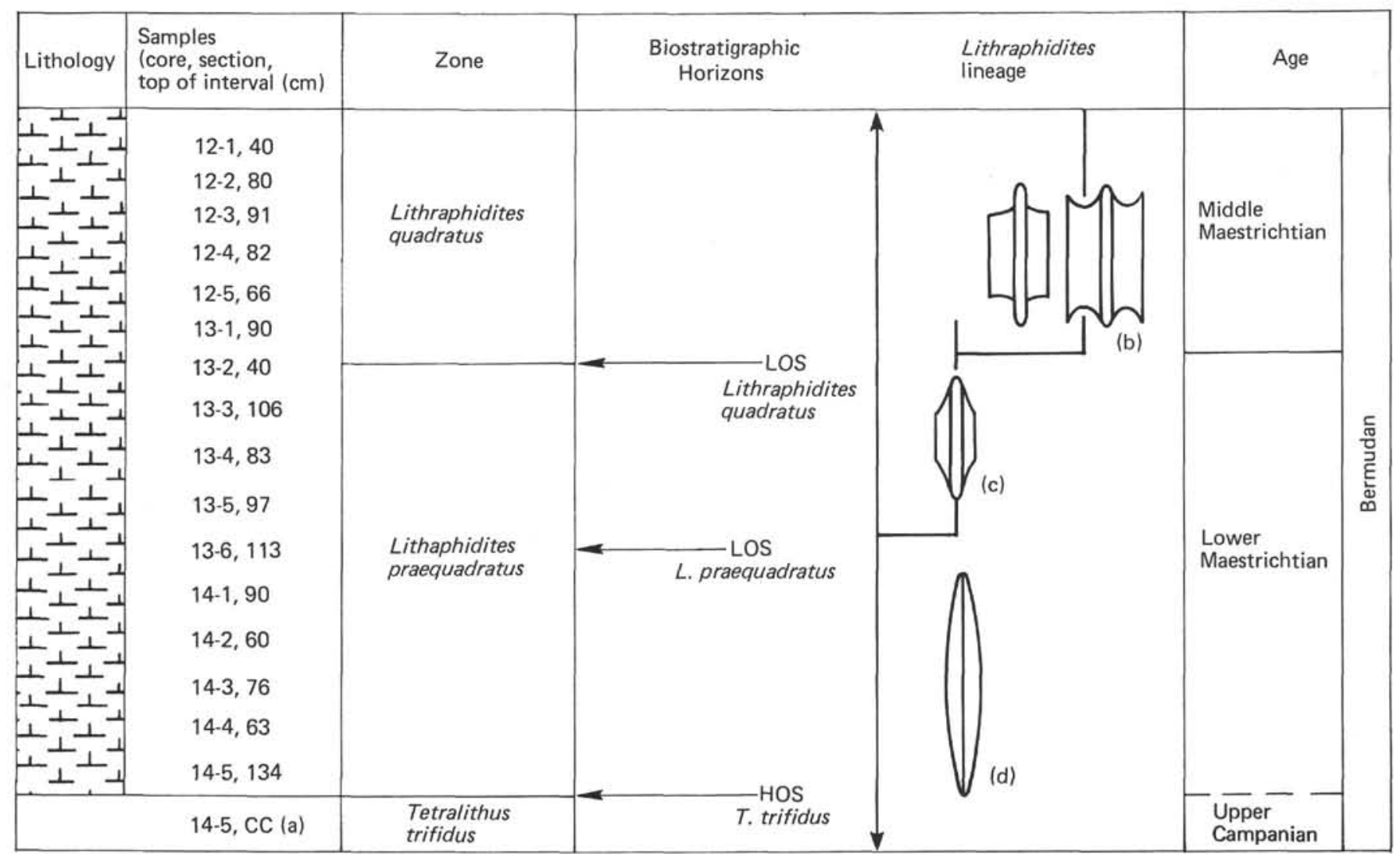

Footnote: (a) according to Schmidt, this volume shipboard paleontologist

(b) Lithraphidites quadratus, normal form (left), extreme form (right)

(c) L. praequadratus $\mathrm{n} . \mathrm{sp}$.

(d) L. carniolensis

Figure 4. Proposed zonation, and biostratigraphic horizons for the Maestrichtian section, Hole 390A. 
Micula mura were observed in Samples 390A-12-1,40 cm and $390 \mathrm{~A}-12-2,80 \mathrm{~cm}$. Thus Core 12 probably belongs to the upper part of the Lithraphidites quadratus Zone. Sample $390 \mathrm{~A}-13-1,90 \mathrm{~cm}$ contains an assemblage similar to the one found in Core 12. In the next lower section (Sample 390A$13-2,40 \mathrm{~cm}$ ) Lithraphidites quadratus is absent, but its ancestor, Lithraphidites praequadratus, is present; it is found in Sections 4 and 5 of Core 13. Section 6 and Core 14 , Sections 1 through 5 are difficult to assign to an existing nannofossil zone. The assemblages include Tetralithus aculeus, Reinhardities anthophora, Cylindralithus serratus, Crepidolithus thiersteinii, Cyclagelosphaera bergeri $\mathrm{n} . \mathrm{sp}$., Tetralithus obscurus and Broinsonia parca, but lack Tetralithus trifidus, the marker for the next lower zone. $T$. trifidus was reported by R. Schmidt, shipboard nannoplanktologist, in the core-catcher sample of Core 15 , but I did not have a sample available for study. The assemblages found in samples from Cores 12 to 14, Section 5 indicate that the sediments are upper Bermudan or lower "Maestrichtian."

\section{The Albian-Aptian}

The mid-Cretaceous section recovered from Hole 390 contains abundant, diversified and well to moderately well preserved coccoliths (Figure 5). Core 3 Sections 1 through 3 contain assemblages including Axopodorhabdus albianus Black (junior synonym: Prediscosphaera? orbiculofenestra Gartner, 1968), Tetrapodorhabdus decorus, Grantarhabdus coronadventis, Prediscosphaera cretacea, Parhabdolithus angustus, $P$. splendens, $P$. asper, $P$. embergeri, Cretarhabdus spectabilis, Zygodiscus diplogrammus, Vagalapilla matalosa, Chiastozygus litterarius, Stephanolithion laffittei, Lithastrinus floralis, Watznaueria barnesae, $W$. ovata, W. biporta, Biscutum supracretaceum, Cyclagelosphaera deflandrei, Nannoconus bucheri, $N$. truittii, and Hayesites albiensis. These assemblages are typical for the Prediscosphaera cretacea Zone (NC7). The assemblage recovered from Core 5, Section $1,48 \mathrm{~cm}$ belongs to the Parhabdolithus angustus Zone. Neither Prediscosphaera cretacea nor Hayesites albiens are present. Discorhabdus biradiatus, Rucinolithus irregularis, and Micrantholithus obtusus occur in small numbers. The assemblages from Core 8 are strongly affected by diagenesis; marker species useful for biostratigraphic age assignment are absent. A Magellanian age seems reasonable but not by any means do I have sufficient evidence to support such an age determination. The lowermost nannofossiliferous sample studied (390-8-6, $118 \mathrm{~cm})$ was contaminated by down-hole displacement of sediment and yielded a Bermudan assemblage. The deepest sample investigated (390-9-1, $105 \mathrm{~cm})$ lacks age-diagnostic coccoliths. Thus, with the samples available to me I cannot determine with certainty the age of Cores 8 and 9 .

\section{Site 391, Hole C (lat $28^{\circ} 13.7^{\prime} \mathrm{N}$, long $7^{\circ} 37^{\prime} \mathrm{W}$, water depth: $4963 \mathrm{~m}$ )}

\section{Lithology}

The Magellanian to Carynian section at Site 391 is one of the most complete records of the Early Cretaceous recovered from the oceans. It is supplemented by other sections drilled at nearby Sites $100,101,105$, and 386 . The Cretaceous sequence is overlain by 650 meters of Miocene to Quaternary hemipelagic clay, chalk, and mudstone. The Cretaceous rests on Upper Jurassic dark red marlstone and variegated limestone. The Carynian and Abacoan stages are composed of about 100 meters of bioturbated white calcilutites with shaly interbeds. The Merrittian stage contains more laminated calcilutites and few bioturbated ones indicating that bottom waters were more poorly oxygenated during the Carynian than Abacoan time. Distal calciturbidite deposits were deposited during the Canaveralian. In the upper Magellanian calcareous claystone with sparse calcilutites mark the beginning of a period of stagnation.

\section{Preservation of Coccoliths}

Overall abundance of coccoliths and their preservation in each sample investigated are listed in Figure 6. The most deeply buried Cretaceous assemblages (Carynian and Abacoan) all show strong diagenetic effects with reduced diversity. The Merrittian and Canaveralian assemblages were affected by more moderate overgrowth, probably because of the higher clay content which resulted in lower permeability of these sediments. The Argusian deposits show signs of increasing dissolution until none of the coccolith carbonates were preserved in the dark gray and greenish Argusian claystones.

The Magellanian to Argusian nannoplankton assemblages at Site 390 are considerably better preserved because they were deposited at shallower depth well above any stagnant deeper water that was poor in $\mathrm{O}_{2}$ and undersaturated with $\mathrm{CaCO}_{3}$.

\section{Nannoplankton Biostratigraphy}

Carynian through Merrittian nannoplankton zones are well represented (Table 3 ), but because of diagenetic changes in the Neocomian calcilutites the important species are difficult to recognize. More detailed work on the genera Zygodiscus, Watznaueria, Retecapsa, and Cretarhabdus is badly needed for more detailed nannoplankton biostratigraphic studies of pelagic limestone sections.

Even the oldest samples studied contained very few Nannoconus. Conusphaera mexicana Trejo (junior synonym: Cretaturbella rothii Thierstein, 1971) is somewhat more abundant in these lowermost samples. Wind (this volume) reports the lowest Nannoconus in the much better preserved assemblages of Core 52, Section 3. The interval between Core 44, Section 5 and Core 42, Section 5 contains Nannoconus, Assipetra infracretacea, and Lithraphidites carniolensis, but lacks Retecapsa neocomiana (=Cretarhabdus crenulatus, pro parte (of Thierstein, 1971, 1973), and therefore belongs to the lower Carynian Zone $\mathrm{NC1}$ (Nannoconus colomii-Lithraphidites carniolensis). The lower Abacoan Zone NC2 (Retecapsa neocomiana) was recovered in Cores 42 (Section 3 ) to 31 (Section 6); its base is marked by the lowest occurrence of the marker species, its top by the lowest occurrence of Tubodiscus verenae. Retecapsa angustiforata, $R$. brightonii, Cretarhabdus primus, and Biscutum supracretaceum make their first occurrence in this zone. In the next higher Zone NC3, Tubodiscus verenae, Diadorhombus rectus, Calcicalathina 


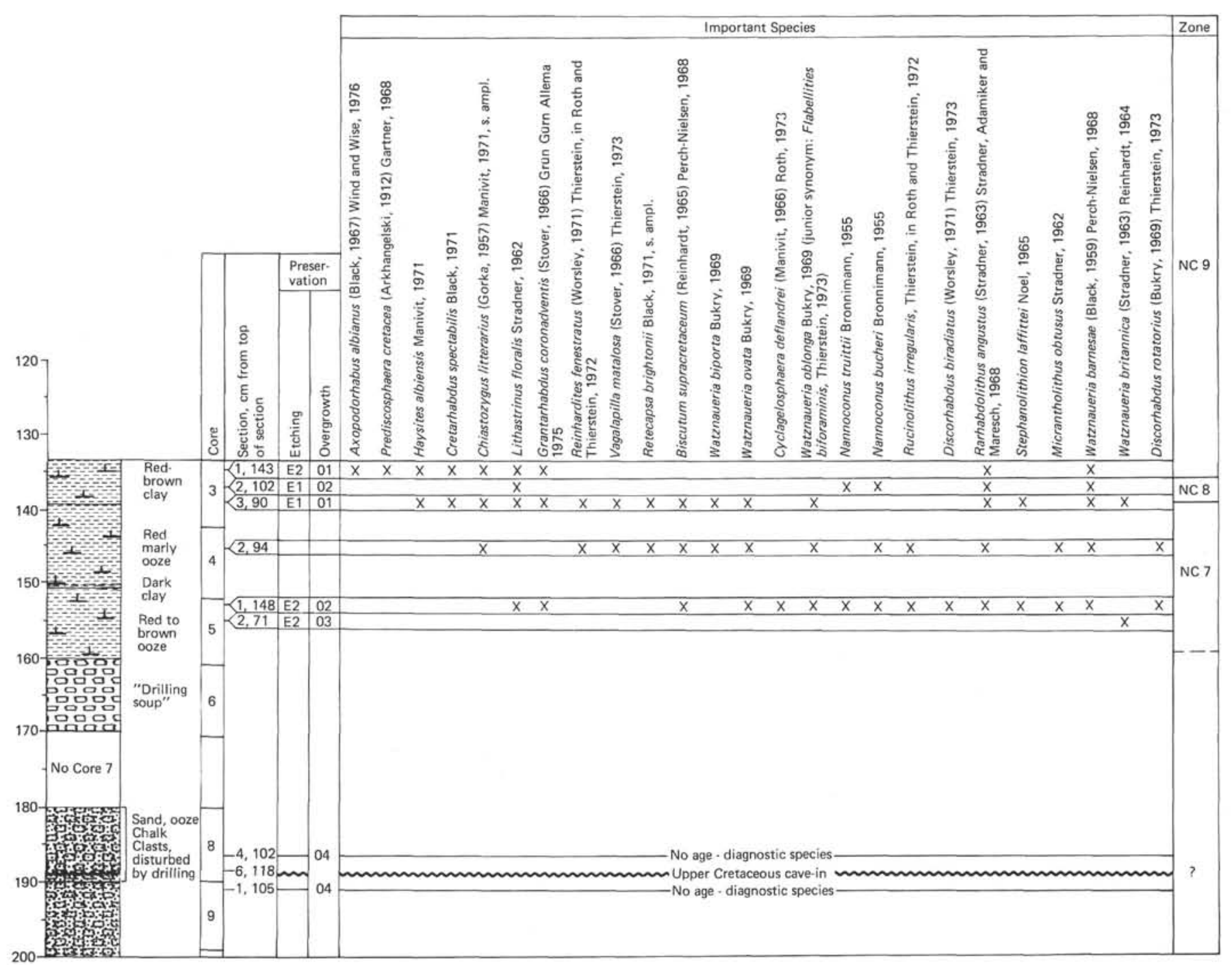

Figure 5. Distribution of speis in the mid-Cretaceous section, Hole 390.

oblongata, and Zygodiscus diplogrammus have their lowest occurrence. Cores 24-31 belong to Zone NC3. The lower boundary of the next higher Zone NC4 characterized by the disappearance of Tubodiscus verenae and Diadorhombus rectus is found in Core 24 . The lowest occurrence of Axopodorhabdus dietzmannii is slightly below the NC3/NC4 boundary. This order of events (lowest occurrence surface [LOS]P . dietzmannii just below highest occurrence surface [HOS] of $T$. verenae) was also observed by Thierstein (1973) in the Orpierre section, Hautes Alpes, Southeast France. Unfortunately, all markers used for this boundary are fairly easily destroyed by diagenesis. The upper boundary of Zone NC4 is probably one of the most easily recognized and most reliable biostratigraphic horizon in the Neocomian, i.e., the HOS of Curciellipsis cuvillieri; it falls between Cores 17 and 16. A subdivision of this zone into NC4a and NC4b was impossible due to the absence of Lithraphidites bollii. Diversities in this zone remain high although there seems to be a slight decrease in the number of species. The next higher zone, the Canaveralian Zone NC5, is only represented by about 10 meters of sediment (Core 16). The facies of the Canaverallian sediments indicates the presence of turbidites. The section is unusually thin and possibly part of the Canaveralian was eroded by strong currents. The late Canaveralian Zone NC6-marked by LOS of Chiastozygus litterarius and Vagalapilla matalosa-is also quite thin and only represented by one sample in this study (391C-15-3, 70 $\mathrm{cm})$. I suspect that part of the upper Canaveralian is also missing. The lower Magellanian Zone NC7 is well represented in this section although increasing dissolution has taken its toll, and destroyed many of the more delicate forms. Only a more detailed study of many more samples would permit recognition of the top of Zone NC7. One sample $(391 \mathrm{C}-9-2,58 \mathrm{~cm})$ studied revealed rims of Prediscosphaera cretacea which would indicate a middle Magellanian age (NC8) for the top of the calcareous claystone unit.

\section{EARLY CRETACEOUS NANNOPLANKTON EVOLUTION, TEMPERATURES, AND FERTILITY: A WORKING HYPOTHESIS}

Geographic reconstructions for the Jurassic and Early Cretaceous show a large Pacific Ocean with a wide connection to the Indian Ocean and Tethys (Briden et al, 1974). The Atlantic Ocean and western Tethys were very narrow at that time (Figure 7). The climate of the Jurassic was 


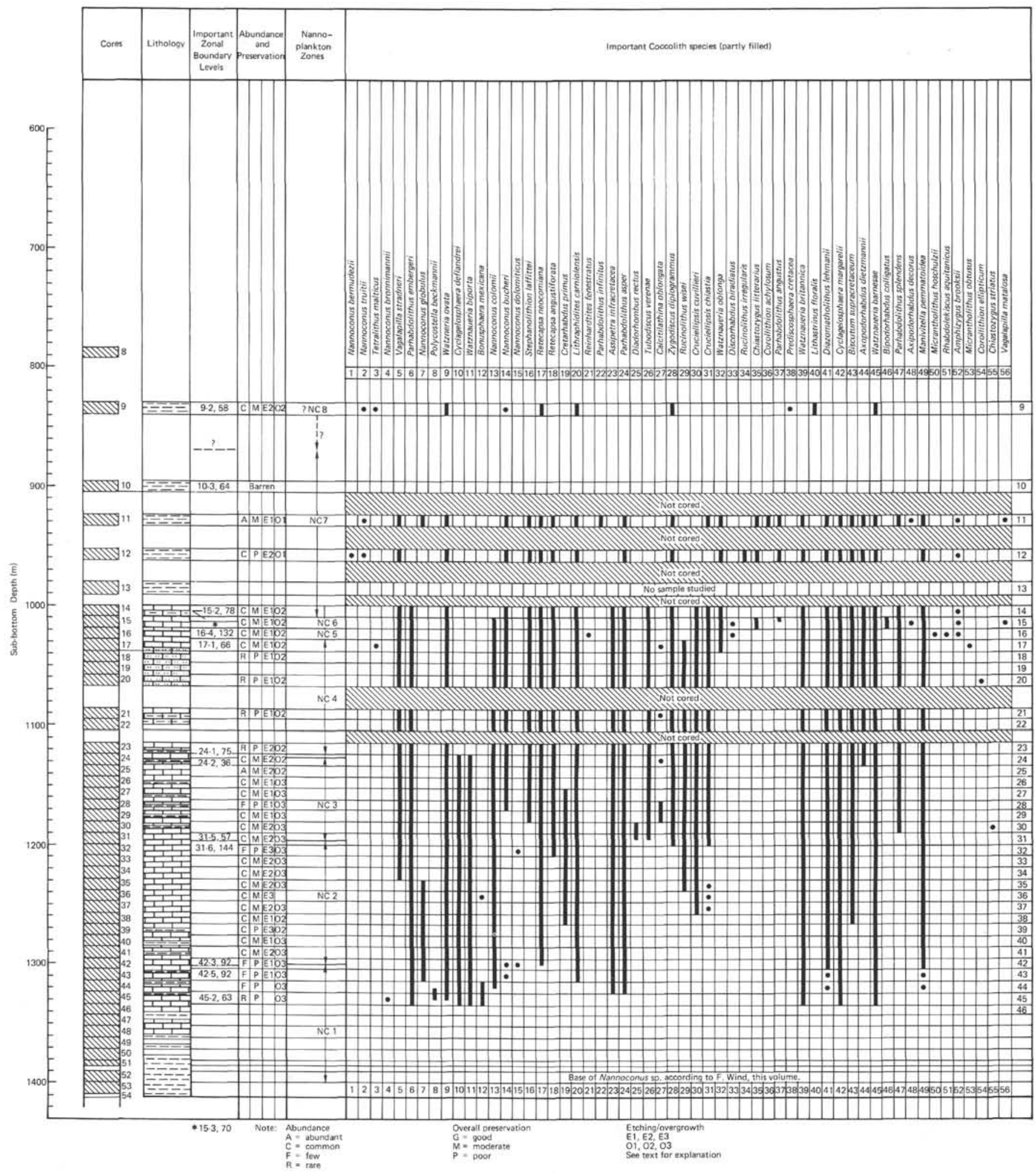

Figure 6. Stratigraphic distribution of coccoliths, Hole 391C.

oceanic with equable temperatures and a fairly wide tropical belt. A strong east/west surface current-here named Tethys Current-dominated the surface circulation in the Atlantic/Tethys/Indian Ocean belt. Connections between the tropical and boreal regions were narrow and shallow (Berggren and Hollister, 1974) and water exchange small compared to the amount of water moved by the Tethys current. In the mid-Cretaceous dense brines formed in extensive evaporite basins along the rifting South Atlantic and in the central American/Caribbean region. Since temperature gradients between high and low latitudes were small at that time, salinity probably determined density of the sea water to a large extent. Highly saline brines from those evaporite basins spilled over the sills and flowed down the 


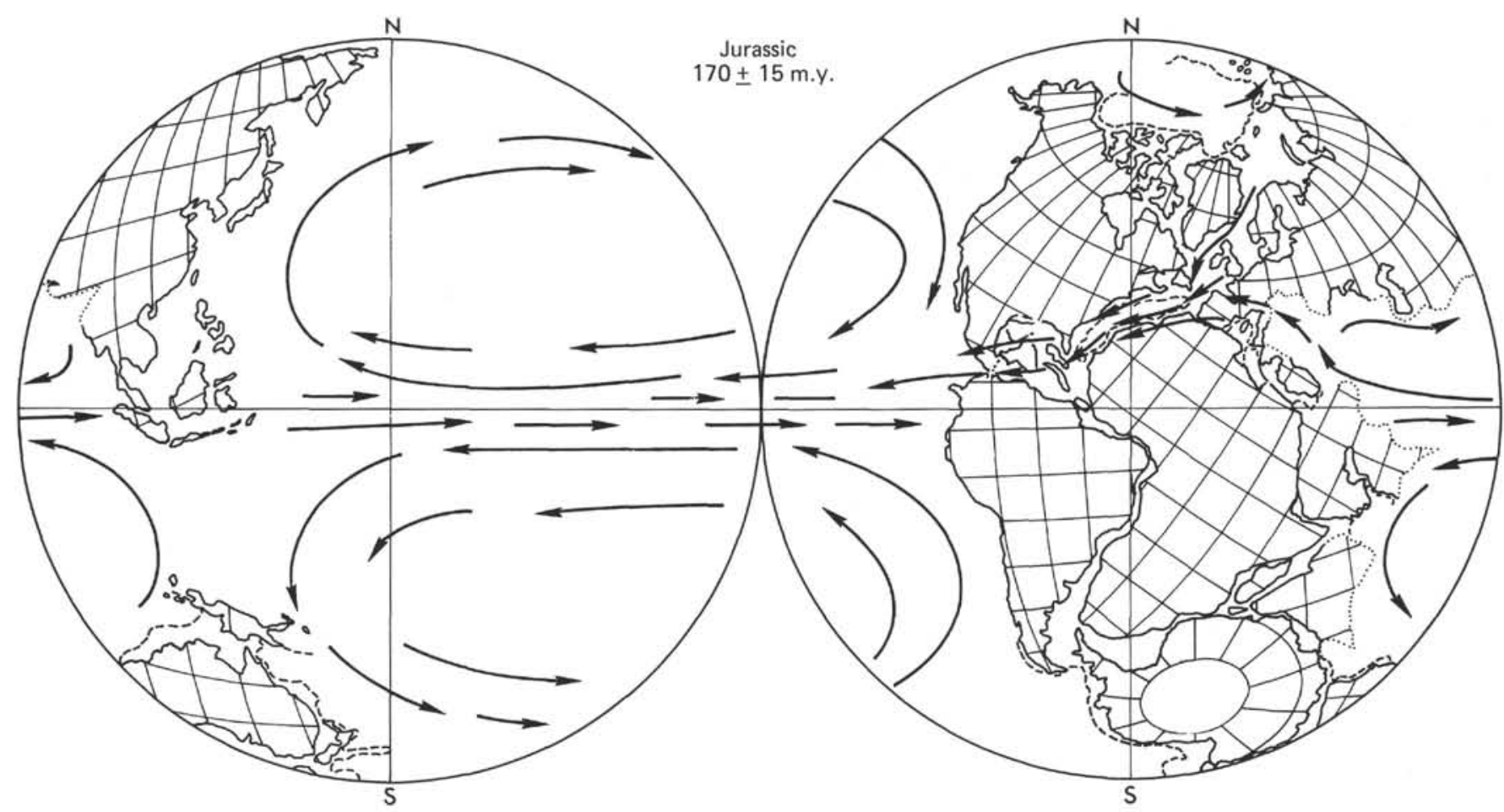

Figure 7a. Distribution of continents and surface water currents during the Jurassic. Reconstruction of continents after Briden et al., 1973.

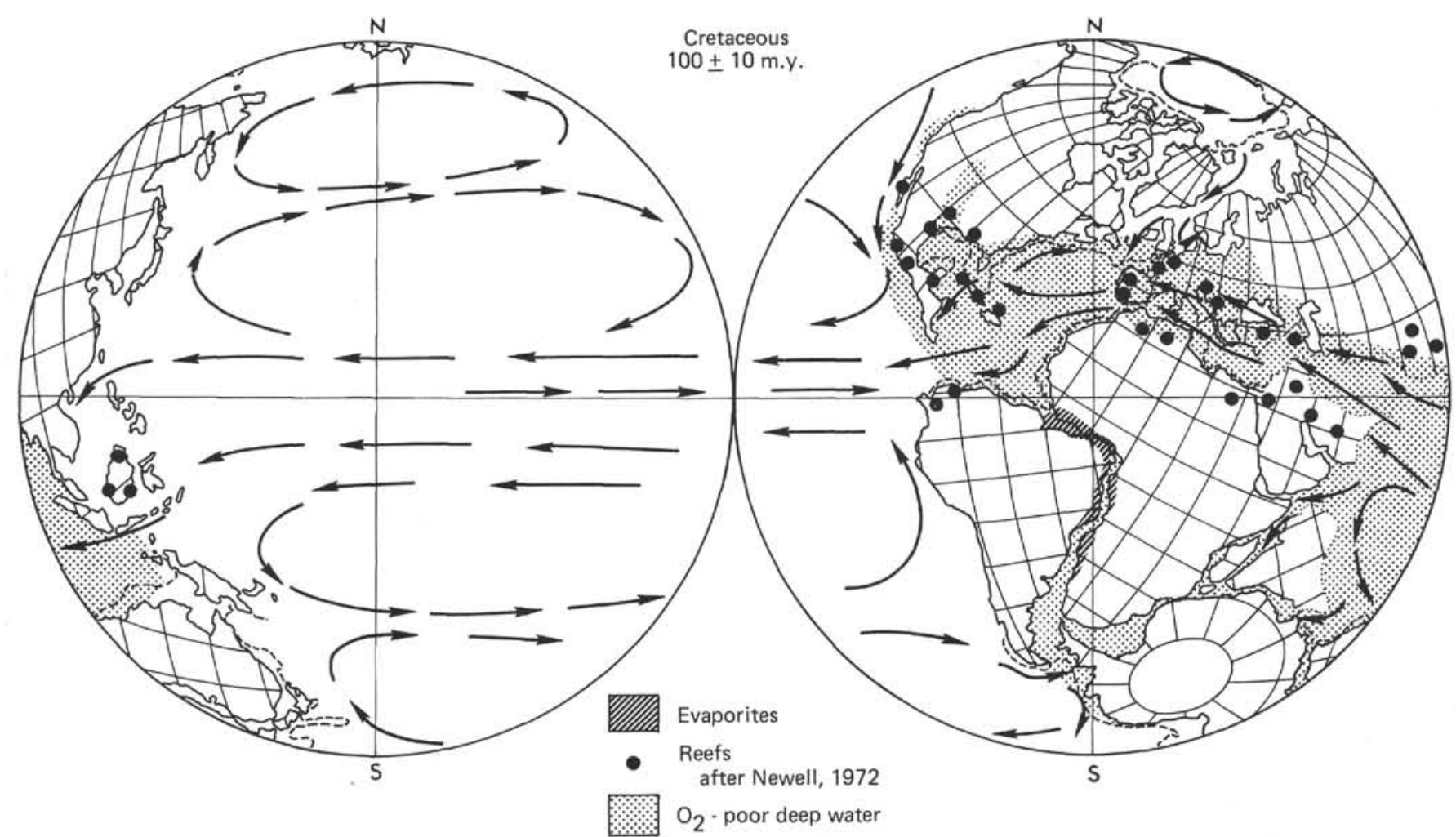

Figure 7b. Distribution of continents, surface water currents, stagnant bottom and deep waters, and reefs during the "mid-

Cretaceous." Reconstruction of continents after Briden et al., 1973.

continental slopes into the Atlantic basins forming dense saline deep waters which, because they were too dense to return to the surface by upwelling, were also poor in oxygen. As a result of stagnation and perhaps also because oxygen was sequestered as gypsum (Funnel, personal communication), extensive oxygen-poor deep, and bottom waters formed an oxygen-minimum zone ranging in depth from about 3000 meters to below 5000 meters in the Atlantic; 
oxygen-poor deep waters also spread to the Indian Ocean (Roth, in press). Extensive denitrification by bacteria in the oxygen-minimum zone led to a reduction in the nitrogen available to primary producers in the surface waters (Figure 8). Productivity dropped considerably around 108 m.y. B.P. as a result of the limited supply of combined nitrogen ("bionitrogen"). Excess phosphate not used up by phytoplankton in the photic zone was precipitated in the interstitial waters of sediments deposited near the boundary of the oxygen minimum zone as it does today in the East Pacific (Veeh et al., 1973; Piper and Codispote, 1975; Manheim et al., 1975). Some phosphate was liberated during disintegration of organic matter which also increased the $\mathrm{pCO}_{2}$ resulting in increased dissolution of carbonates.

Phosphorites are quite common in mid-Cretaceous sediments as one would expect. Nutrients brought in by rivers were largely sequestered in extensive shallow water reefs in the tropical Tethys (shelf-basin fractionation, Berger and Roth, 1975). While surface water fertility and calcareous plankton productivity were low during the Magellanian and Argusian stages (108 to 95 m.y. B.P.), diversity of calcareous nannoplankton started to increase rapidly (Figure 9). Increased cropping of calcareous nannoplankton by microzooplankton was probably responsible for this rapid diversification, especially among parhabdolithids and podorhabdids and eiffellithids. A well-documented increase in abundance and diversity of planktic foraminifers (Figure 10) could indicate a general increase in herbivorous microzooplankton during the mid-Cretaceous; only foraminifers and radiolarians left a fossil record, but other predators might have been more important. Rapid sea-floor spreading during the Magellanian and Argusian time resulted in large-scale transgressions (Hays and Pitman, 1973). During the same time the magnetic polarity was normal-a fact that contradicts the hypothesis that reversals of the earth's magnetic field leads to rapid plankton evolution. Increased meridinal circulation caused by the opening of the
South Atlantic, a widening of the passages between the boreal seas and the Atlantic (Figure 7), and the formation of the western interior seaway around $90 \mathrm{~m}$.y. B.P. lead to general cooling, increased vertical and horizontal temperature gradients and thus better mixing of the oceans. Atlantic Ocean and Indian Ocean deep and bottom waters became oxygenated again as indicated by a change from sediments deposited under reducing conditions to sediments deposited under oxidizing conditions. Calcareous plankton productivity increased while diversity remained high during the Late Cretaceous. The final extinction of most calcareous plankton species at the end of the Cretaceous is still poorly understood. An excess of carbonate production by coccoliths during the Late Cretaceous might have gradually decreased the total carbon dioxide content of the ocean/atmosphere system (Funnel, personal communication, 1975). The oceans responded by dissolving more carbonates which led to a shallowing of the calcium carbonate compensation depth (CCD) at the end of the Cretaceous (Worsley, 1974).

Perhaps calcium carbonate removal from ocean surface waters by coccolithophorids was so great at the end of the Cretaceous that the dissolved $\mathrm{CO}_{2}$ concentration in the surface waters of the oceans fell below the threshold level for coccolith production. Naked strains might have survived this adverse period. The work by Paasche $(1964,1968)$ shows that in laboratory cultures, coccolith production is the first process to be affected by adverse conditions; photosynthesis continues although at a reduced rate. Goldman (1972) showed that a reduction of total $\mathrm{CO}_{2}$ concentration below 10 $\mu \mathrm{m}$ leads to a rapid drop in the growth of Selenastrum capricornutum. The total $\mathrm{CO}_{2}$ concentration of ocean water is close to the above value and thus it does seem possible that extreme depletion of carbon dioxide in the ocean-atmosphere system could affect phytoplankton productivity. Calcium probably did not become a limiting element for coccolith growth as suggested by Edwards (1973) because coccolith production is only affected if calcium drops to values about

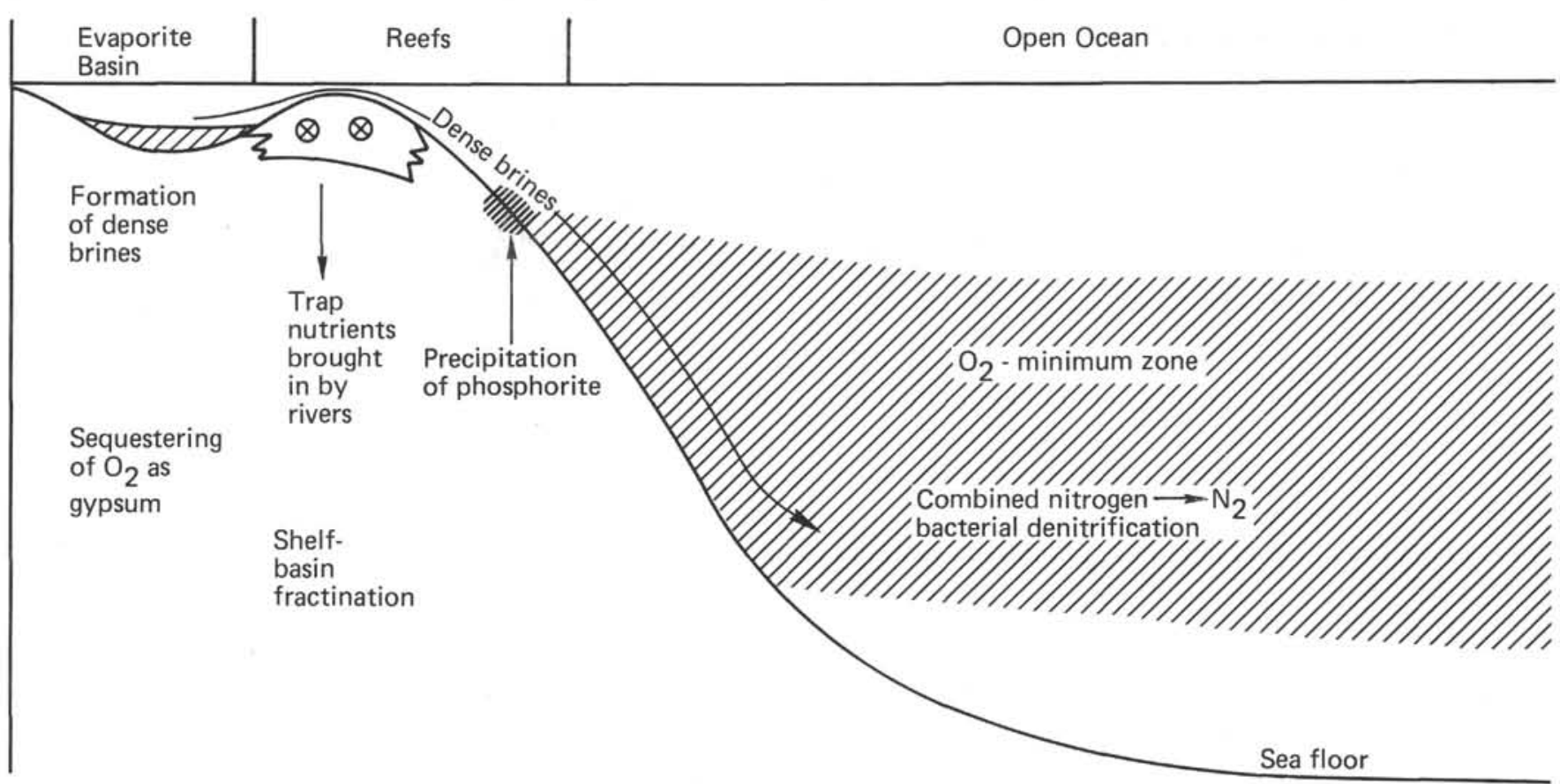

Figure 8. Fertility model of the stagnant Atlantic-Tethys-Indian Ocean during the "mid-Cretaceous." 

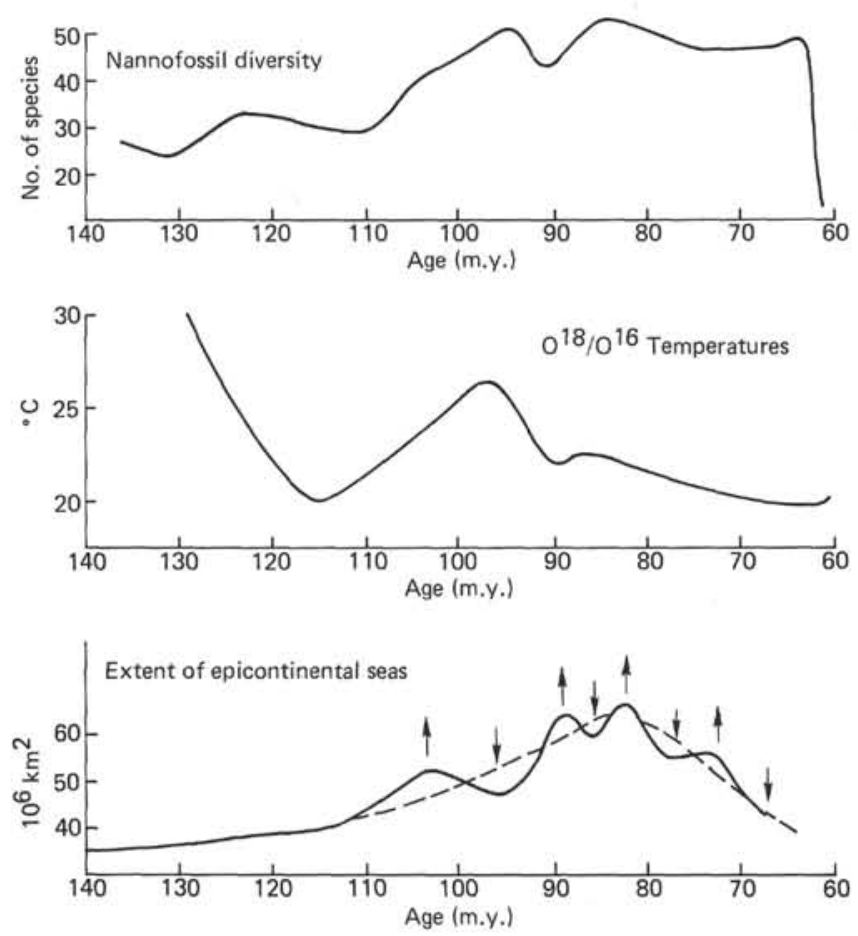

Figure 9. Nannofossil diversity, temperatures, and extent of epicontinental seas. After Roth, in press.

two orders of magnitude below the present-day calcium concentrations in the oceans.

The atmosphere is a small reservoir for $\mathrm{CO}_{2}$ (Garrels and Perry, 1975) and a drop in the total dissolved carbon of the ocean could not be offset by a flux from the atmosphere to the ocean. Only an exchange with the much larger sedimentary rock reservoir would return the dissolved carbon content to normal values.

Reduced total $\mathrm{CO}_{2}$ in the atmosphere/ocean system during a time period of perhaps $10^{4}$ to $10^{5}$ years could affect phytoplankton production severely and also explain lowered temperatures observed for the latest Cretaceous. Most of the highly evolved and well adapted Cretaceous nannoplankton groups could not survive the period of lowered dissolved $\mathrm{CO}_{2}$ concentration and decreased water temperature. The only survivors among the coccolithophorids of the latest Cretaceous were hardy placolith-bearing forms and encysting groups (Braarudosphaera and Thoracosphaera); these completely dominate many earliest Tertiary nannofossils assemblages. This major extinction in the first trophic level led to a rapid extinction in the next higher trophic level (planktonic foraminifers and radiolarians).

Extensive dissolution of calcium carbonates during the time period just following the major extinctions of coccolithophores led to a rapid increase in the total $\mathrm{CO}_{2}$ content of oceans and atmosphere. Calcareous ooze deposition quickly resumed in the lower Tertiary although at slightly lower rates.

These ideas are obviously very speculative and need further testing. It is essential that quantitative data on the nannoplankton assemblages for the Cretaceous are gathered as well as careful sedimentological and geochemical investigations are undertaken to test this working hypothesis. A more detailed discussion of Cretaceous nannoplankton diversity and paleoceanography appears in Roth (in press).

\section{SYSTEMATIC DESCRIPTIONS}

Cyclagelosphaera bergeri n.sp.

1968 Markalius circumradiatus (Stover, 1966) of Perch-Nielsen, 1968, p. $73-75$, text-fig. 36,37 , pl. 25 , fig. $2-8$, pl. 26 , fig. 1-7.

Holotype: Specimen illustrated in Perch-Nielsen, 1968, on pl. 26, fig. 3-5.

Definition: A circular to semicircular placolith composed of a distal shield with about 30 to 40 dextrally imbricate elements in the outer circle and slightly fewer tabular elements in the inner circle central are filled by a third cycle of blocky crystallites. In the light microscope this species is characterized by high birefringence, an extinction cross with only slightly curved arms which are slightly offset between the central area and the rim.

Differential Diagnosis: The new species is very similar to Watznaueria barnesae in the light microscope, but it is circular instead of elliptical. Haqius circumradiatus $\mathrm{n}$. comb. is composed of much thinner shields and is weakly birefringent in the light microscope. Cyclagelosphaera reinhardtii n. comb. (Basionym: Markalius reinhardti Perch-Nielsen, 1968 , p. 76 , text-fig. 38 , pl. 23 , fig. 6-8) differs from C. bergeri in having a cone-shaped raised central area composed of strongly imbricate plates. In the light microscope one observes that arms of the extinction cross in the central area are more strongly offset with respect to the cross arms on the outer part of the shield. Cyclagelosphaera deflandrei (Manivit) Roth, 1973 is larger and much thicker than $C$. bergeri $\mathrm{n}$. sp.; it often shows yellow colors under crossed nicols.

Cyclagelosphaera margareli is much smaller in overall size and has a smaller central area than Cyclagelosphaera bergeri.

Cyclagelosphaera rotaclypeata Bukry, 1969, differs from C. bergeri in having a narrow second cycle of elements in the distal shield and a wide central area filled with irregular laths.

Derivation of name: Named after Wolfgang $H$. Berger in recognition for his work on deep-sea carbonates and paleoceanography.

Remarks: Haqius circumradiatus n. comb. is often misidentified. Thus, neither Cyclagelosphaera deflandrei (Manivit) nor $C$. bergeri are synonymous with Haqius circumradiatus (Stover) n. comb. because they are highly birefringent.

Biostratigraphic range: Bermudan (uppermost Tetralithus trifidus Zone) to Danian (Markalius inversus Zone). The stratigraphic and taxonomic significance of Cyclagelosphaera bergeri was suggested by M. N. Bramlette (personal communication, 1975).

\section{Genus HAQIUS}

Definition: Circular placoliths composed of two shields with 40 or more slightly dextrally imbricated elements. Suture lines seen from the distal side are straight. Birefringence is weak, and the extinction cross diffused much like Reticulofenestra of the Cenozoic. This diffuse extinction figure is caused by the slight amount of imbrication. Central area about one-half the total diameter, with or without an inner cycle of plates.

Differential diagnosis: Markalius Bramlette and Martini, 1964, differs from Haqius n. gen. in having strongly curved suture lines, a very highly birefringent central area and almost no extinction figure on the outer part of the shield.

Striatococcolithus Bukry, 1971 has weakly birefringent shields like Haqius but its central area is much smaller (only $15 \%$ of distal shield).

Cyclagelosphaera Noël, 1965, has strongly imbricate elements and high birefringence in the center and the rim of the shields.

Genotype: Haqius circumradiatus n. comb.

Remarks: Haqius circumradiatus $\mathrm{n}$. comb. is the only species assigned to the new genus so far.

Derivation of name: Named after Bilal Haq in recognition for his work on Cenozoic nannoplankton.

Haqius circumradiatus n. comb.

1966 Coccolithes circumradiatus Stover, 1966, p. 138, pl. 5, fig. 2-4, pl. 9, fig. 10.

non 1968 Markalius circumradiatus (Stover, 1966) Perch-Nielsen, p. 73, pl. 25 , fig. $2-7$, pl. 26 , fig. 1-7, text-fig. 36-37.

non 1970 Markalius circumradiatus of Noël, p. 93, pl. 36, fig. 1-7.

1971 Markalius circumradiatus of Manivit, p. 116, pl. 26, fig. 1-5.

1971 Markalius circumradiatus of Thierstein, 1971, p. 479, pl. 4, fig. $1-5$.

1976 Markalius circumradiatus of Hill, 1976, p. 145, pl. 8, fig. 26-27.

Remarks: The diagnosis for the genus is identical to the one for this species. Hill (1976) gives an excellent description of this species in the light microscope. Thierstein (1971) furnished electron microscope pictures of this 


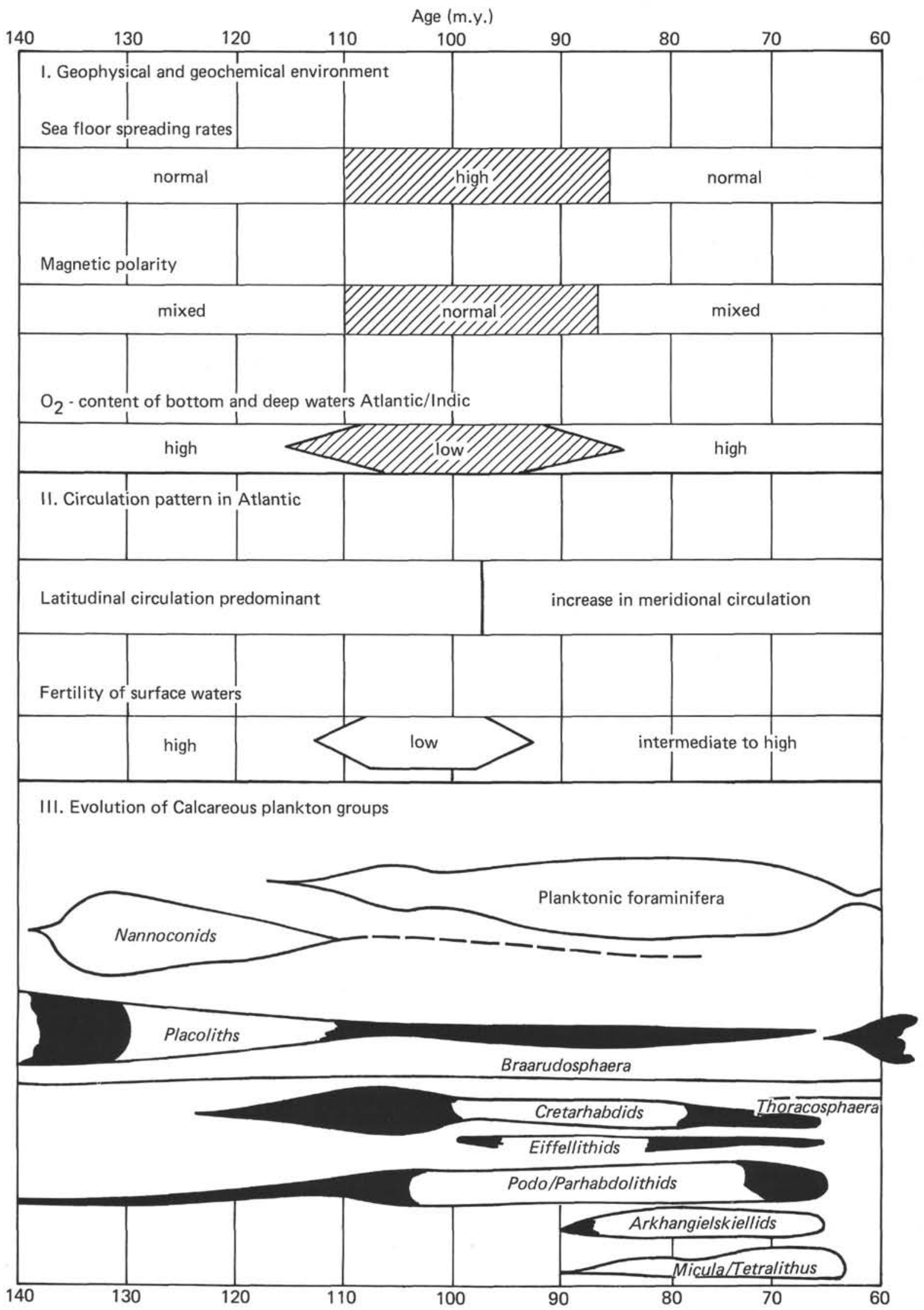

Figure 10. Sea-floor-spreading rates, magnetic polarities, surface and deep water circulation, fertility of surface water, and distribution of important calcareous plankton groups. 


\section{P. H. ROTH}

species. We can clearly see on these illustrations that the elements of the distal shield are narrow, slightly imbricate dextrally, and separated by straight suture lines. The central area may or may not contain small crystallites, depending on preservation. The proximal shield-if the specimen shown by Thierstein (1971) is indeed Haqius circumradiatus and not $\mathrm{Cyc}$ lagelosphaera margareli-shows three cycles of elements with suture lines inclined in opposite directions and a central area filled with laths and small tabular elements.

Range: Lower to Middle Cretaceous.

\section{Subfamily RETECAPSOIDEAE Black, 1973}

Thierstein (1971) recognized that this group of Cretaceous coccolithophores has biostratigraphic potential. Black $(1971,1973)$ admirably described many species of the Lower Cretaceous Retecapsoidea from the Speeton Clay and the Gault Clay. He says, "Cretarhabdus and Retecapsa are particularly variable and consequently difficult to classify; at first sight there appears to be an almost continuous variation, but if numbers are taken into account, there is a strong statistical clustering about a few separate modes, intermediate forms being comparatively rare" (Black, 1971, p. 387). Black (1971) did not present any light micrographs of Retecapsa and only one electron micrograph for each species; three additional electron micrographs of the most highly evolved form, Retecapsa levis were presented in Black (1973). Black described the Neocomian forms rather briefly and did not show the overall variability of the various Retecapsa species. This resulted in some confusion in subsequent biostratigraphic publications. Bukry (1973) clearly recognized that Thierstein (1971) had excluded the type specimens of Cretarhabdus crenulatus Bramlette and Martini from his emended Cretarhabdus crenulatus Bramlette and Martini, emend. Thierstein, 1971. Thus, Bukry (1973) put Thierstein's C. crenulatus (with 8 struts) into synonymy with Cretarhabdus angustiforatus (Black) Bukry, 1973. However, subsequent investigators did not follow Bukry's suggestion. Grün (in Grün and Allemann, 1975) puts Retecapsa laevis, $R$. neocomiana of Black, 1971, and Cretarhabdus crenulatus of Thierstein, 1971, in synonymy with Retecapsa angustiforata and transfers Cretarhabdus crenulatus to the Genus Retecapsa. Hill (1976) in his study of the AlbianCenomian of the Gulf Coast comes to a different conclusion. He considers Retecapsa neocomiana and (questionably) $R$. angustiforata synonymous with $R$. levis.

My investigation of Lower Cretaceous sediments from the Atlantic and earlier studies on Pacific sediments lead to the following results concerning Retecapsa (see also Figure 11 and Plate 1, Figures 1-5):

1) The earliest form is Retecapsa neocomiana, a small species of Retecapsa with central area with a width of $1 / 2$ or less of the total width of the distal shield and very small openings between the struts (for light micrograph see Plate 1, Figure 1). $R$. neocomiana first occurs in the "Abacoan" and ranges throughout much of the "Canaveralian."

2) $R$. angustiforata evolved from Retecapsa neocomiana by increasing its size and developing somewhat larger pores and an inner cycle of elements surrounding the central area. These forms here assigned to Retecapsa angustiforata developed during the Abacoan and Merrittian when they started to dominate.

3) Retecapsa brightonii is difficult to recognize in the light microscope. It differs from $R$, angustiforata in having a larger central area and a narrower cycle of elements surrounding the central area. It seems to have evolved at roughly the same time as $R$. angustiforata during the Merrittian.

4) Retecapsa levis evolved from $R$. angustiforata in the latest Canaveralian to mid-Cretaceous. It has greatly increased central pores in its wide central area and gave rise to Retecapsa schizobrachiata $\mathrm{n}$. comb., in the later part of the mid-Cretaceous and Late Cretaceous. In $R$. schizobrachiata the pores between the bifurcating crossbars in the long axis of the coccoliths have almost completely disappeared.

\section{Retecapsa angustiforata Black, 1971}

(Plate 1, Figures 3-5)

1971 Retecapsa angustiforata Black, p. 409, pl. 33, fig. 3

1971 Cretarhabdus crenulatus of Thierstein, 1971, p. 476-477, pl. 6, fig. 10-14

1973 Cretarhabdus angustiforatus (Black) Bukry, partim, p. 677, pl. 2, fig. 4-6 (not fig. 7)

Remarks: This species differs from $R$. neocomiana in having a larger central area and surrounded by a cycle of elements separated from the rim by a series of shallow pits. $R$. brightonii has a narrower cycle of more clearly defined crystallites surrounding a relatively large central area. The diameter of the perforations between the struts is definitely smaller than the width of

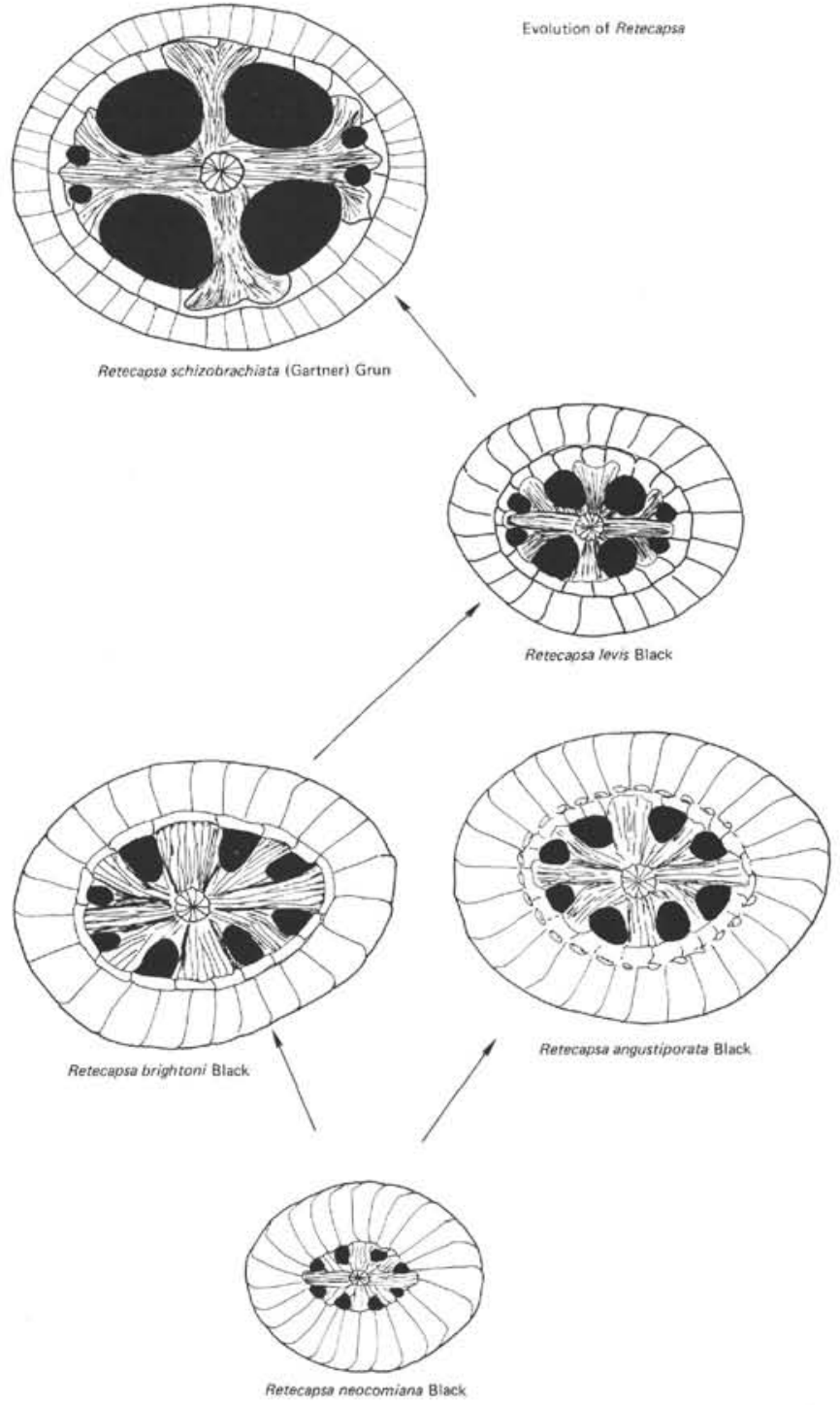

Figure 11. Evolution of Retecapsa Black, 1971 during the Early to Late Cretaceous. Retecapsa neocomiana is the oldest species and gave rise to $\mathrm{R}$. angustiforatus and $\mathrm{R}$. brightonii, the dominant forms in the late "Neocomian" and "mid-Cretaceous." Retecapsa levis is best developed in the Albian and gives rise to R. schizobrachiatus in the Late Cretaceous. Drawings are schematic, after Black, 1971, 1972; Hill, 1976; Gartner, 1958; Bukry, 1969; and Grun and Allemann, 1975.

the struts. The central area is elliptical in $R$. angustiforata, slightly diamond-shaped in typical $R$. neocomiana.

Size: $8 \times 6.7 \mu \mathrm{m}$, width of central area greater than 0.5 times total width of shield.

Range: Base in Abacoan, ranges up into the mid-Cretaceous, perhaps into the lower part of the Upper Cretaceous.

\section{Retecapsa brightonii Black, 1971} (Plate 1, Figures 2a-c.)

1971 Retecapsa brightonii, Black, p. 409, pl. 33, fig. 3 .

Remarks: This well-defined species with a cycle of narrow elements surrounding the central area is difficult to recognize with certainty in the light microscope owing to the considerable degree of overgrowth in the Neocomian pelagic limestones investigated here. The form illustrated on Plate 1 , Figure 2 , is tentatively assigned to this species because an inner cycle is faintly visible. 
Size: Maximum diameter $7.2 \mu \mathrm{m}$, central area almost exactly 0.5 times total length.

Range: Upper Abacoan to Canaveralian.

\section{Retecapsa levis Black, 1971}

1971 Retecapsa levis Black, p. 410, pl. 33, fig. 1.

1972 Cretarhabdus crenulatus Bramlette and Martini, of Roth and

Thierstein, pl. 5, fig. 10,11.

1973 Retecapsa levis Black, p. 40, pl. 10, fig. 1-3.

1976 Retecapsa levis Black, Hill, p. 152-153, pl. 5, fig. 15-19.

Remarks: Retecapsa levis is the best described species of this genus. It is distinguished from all other species of Retecapsa by having four large pores in the center and four smaller pores between the struts of the longer axial cross arm.

Size: Large diameter $5.8 \mu \mathrm{m}$, diameter of central area larger than 0.5 times diameter of shield.

Range: "Barremian" to "Middle Cretaceous" (Black, 1971, 1973). This species is more abundant in younger sediments than those investigated in this study.

\section{Retecapsa neocomiana Black, 1971}

(Plate 1, Figures 1a-c)

1971 Retecapsa neocomiana Black, p. 410 , pl. 33 , fig. 2

1972 Cretarhabdus crenulatus Bramlette and Martini, of Roth and Thierstein, pl. 1.5, fig. 12 (not fig. 10, 11)

1973 Cretarhabdus angustiforatus (Black) Bukry, p. 677, pl. 2, fig. 7 (not fig. 4-6)

1975 Retecapsa angustiforata Black, of Grün, p. 173, pl. 4, fig. (?)1, 2, $(?)^{3} \mathrm{fi}$

Remarks: This species is characterized by a small overall size and a relatively small central area. There is no intermediate cycle of elements between the shield and the central area.

Range: $R$. neocomiana is the oldest species of the genus Retecapsa. Its lowest occurrence is in the Carynian as used here. It seems to become rare in the Canaveralian where $R$. angustiforata and $R$. levis become dominant.

Size: Maximum diameter 5.5 meters; central area 0.6 times total diameter.

\section{Genus CRETARHABDUS Bramlette and Martini, 1964}

Remarks: The type specimen of this genus has not been well illustrated; we follow the emendation of this genus by Bukry, 1969. The rim structure is quite different from Retecapsa. Cretarhabdus shows a distal shield composed of two cycles of slightly off-set elements whereas Retecapsa has a shield composed of a broad cycle of elements; in some of the species we find a narrow cycle of elements lining the central area. Also, as Black (1973) points out, in Cretarhabdus a granular membrane fills the space between the struts whereas Retecapsa has open pores.

Synonyms: Allemanites, Grün, 1975; Miravetesina, Grün, 1975; ?Stradneria, Reinhardt, 1964.

\section{Cretarhabdus crenulatus Bramlette and Martini, 1964}

Synonymy: see Bukry, 1973, p. 677.

Remarks: This species is used for forms with more than 8 struts and the typical rim structure illustrated by Bukry (1969).

Range: "Middle" to "Upper Cretaceous."

\section{Genus CRUCIELLIPSIS Thierstein, 1971, emend. 1973}

Remarks: The original description of this genus was emended by Thierstein (1973) to include species with a central boss or stem. The unavailability of Helenea Worsley, 1971, was indicated but the difference between Cruciellipsis and Microstaurus Black, 1971, was not discussed. The similarity in the ultrastructure of Cruciellipsis chiasta, Microstaurus lindensis, and $M$. quadratus is so great that they should be included in the same genus.

Cruciellipsis chiasta (Worsley) Thierstein, in Roth and Thierstein, 1972

1971 Helenea chiasta Worsley, p. 1310, pl. 1, fig. 42-44.

1971 Microstaurus lindensis Black, 1971, p. 405, pl. 32, fig. 1.

1973 Microstaurus lindensis Black, 1973, p. 45, pl. 13, fig. 1-3.

Non 1975 Microstaurus chiastus (Worsley) Grün, in Grün and Allemann,

p. 181, pl. 5, fig. 1-3. (=Microstaurus quadratus Black, 1971)
Remarks: Cruciellipsis chiasta as illustrated by Thierstein (in Roth and Thierstein, 1972) clearly shows strongly curved suture lines on its distal shield. Microstaurus quadratus Black, 1971, has straight suture lines. Further studies of Cruciellipsis chiasta, Microstaurus quadratus and related forms are needed to fully understand their relationship.

Lithraphidites quadratus, Bramlette and Martini, 1964, emend. (Plate 3, Figure 6)

1964, Lithraphidites quadratus, Bramlette and Martini, 1964, p. 310 , pl. 6 , fig. 16,17 , pl. 7 , fig. 8 .

1968, Lithraphidites quadratus of Gartner, 1968, p. 43, pl. 2, fig. 3, pl. 3, fig. 3, pl. 5, fig. 1,2 .

1968, Lithraphidites quadratus of Perch-Nielsen, p. 84, pl. 25, figs. 8, 9. 1970, Lithraphidites quadratus of Reinhardt, proparte, p. 73, fig. 76, (non pl. 6, fig. 6).

1971, Lithraphidites quadratus of Cita and Gartner, pl. 8, fig. 2.

1976, Lithraphidites quadratus of Verbeek, 1976, pl. 3, fig. 4.

Remarks: Lithraphidites quadratus evolved from $L$. praequadratus by increasing the width of its keels and decreasing the overall length. We propose to reserve the name $L$. quadratus for species with a length/width ratio of 3.5 and less. Forms with a length/width ratio of 5.0 and more belong to $L$. carniolensis.

Lithraphidites sp. cf. L. quadratus of Gartner, 1968 (pl. 6, fig. 9) is considered an extreme form of Lithraphidites quadratus and included in Lithraphidites quadratus, at least until its geographic and biostratigraphic distribution becomes better known. Etching and secondary overgrowth change the appearance of Lithraphidites considerably. Great care has to be taken not to identify broken Lithraphidites carniolensis or $L$. praequadratus as L. quadratus. However, I do not agree with Reinhardt (1970) who considers $L$. grossopectinata Bukry, 1969 , merely as an etched $L$. quadratus; the groove pattern is too regular and appears on all keels and seems a primary feature.

Size: Length 7.0 to $11 \mu \mathrm{m}$, width: $2-3.5 \mu \mathrm{m}$.

Range: Globotruncana gansseri Zone, Bermudan Stage (lower Maestrichtian to middle Maestrichtian)

Paleoecology: More common in mid to high latitudes, rare to absent in equatorial regions.

\section{Lithraphidites praequadratus n. sp.} (Plate 3, Figures 1-3.)

Description: An elongate ortholith composed of four keel-like ridges at right angles to each other. The keels have parallel sides over more than two-thirds of their total length. The total width (both keels are central axis) is 3.6 to 4.9 times the total length. The keels are either truncated or taper at one or both ends.

Differential diagnosis: Lithraphidites praequadratus differs from $L$. carniolensis Deflandre, in its smaller length/width ratio ( $L$. carniolensis has a length/width ratio equal to or greater than 5.0 and can be as high as 11.0) also $L$. carniolensis has a fusiform shape and does not show truncated keels except in broken specimens. L. quadratus Bramlette and Martini emend. has rectangular to trapezoidal keels and a length/width ratio of 3.5 or less. Lithraphidites alatus Thierstein, in Roth and Thierstein, 1972, has triangular to spike-shaped keels. L. grossopectinatus Bukry, 1969 has groove-patterns on all its keels.

Holotype: Specimen illustrated on Plate 3, Figure 1.

Paratypes: Specimens illustrated on Plate 3, Figures 2, 3

Size: Length: $9.4 \mu \mathrm{m}$, width $2.2 \mu \mathrm{m}$ (Holotype).

Range: Globotruncana tricarinata Zone to $G$. gansseri Zone, upper Bermudan Stage (lower Maestrichtian to middle Maestrichtian).

Paleoecology: More common in mid to high latitudes, rare to absent in equatorial regions.

\section{ACKNOWLEDGMENTS}

I am grateful to Dr. D. Bukry (U.S. Geological Survey) and Dr. H. R. Thierstein (Scripps Institution of Oceanography) for their critical review which helped to improve this preliminary report. Mr. J. Bowdler (University of Utah) helped with the scanning electron microscopy. The equipment used in this study was provided by the University of Utah. This research was supported by a grant from the University of Utah Research Fund and by National Science Foundation Grant OCE 76-21561. 


\section{REFERENCES}

Adelseck, C. G., Geehan, G. S. and Roth, P. H., 1973. Experimental evidence for the selective dissolution and overgrowth of calcareous nannofossils during diagenesis: Geol. Soc. Am. Bull., v. 84 , p. $2755-2762$.

Arkhangelsky, A. D., 1912. Upper Cretaceous deposits of East European Russia: Mater. Geol. Russ., 25.

Beckmann, J. P., 1972. Foraminifera and some associated microfossils of Sites 135 to 144 .In Hayes, D. E., Pimm, A. C., et al., Initial Reports of the Deep Sea Drilling Project, Volume 14: Washington (U.S. Government Printing Office), p. $389-420$.

Berger, W. H. and Roth, P. H., 1975. Oceanic micropaleontology: Progress and prospect: Rev. Geophys. Space Phys., v. 13, p. 561-585, p. 624-635.

Berggren, W. A. and Hollister, C. D., 1974. Paleogeography, paleobiogeography and the history of circulation in the Atlantic Ocean. In Hay, W. W. (Ed.), Studies in Paleo-Oceanography: Soc. Econ. Paleont. Mineral. Spec. Publ. 20, p. 126-186.

Black, M., 1967. New names for some coccolith taxa: Geol. Soc. London Proc., v. 1640 , p. $139-145$.

- 1971. Coccoliths of the specton clay and Sutterby Marl: Yorkshire Geol. Soc. Proc., v. 38, p. 381-424.

- , 1972. British Lower Cretaceous coccoliths, I, Gault Clay: Paleontogr. Soc. Monogr., pt. 1, p. 1-48.

, 1973. British Lower Cretaceous coccoliths, I, Gault Clay: Paleontogr. Soc. Monogr., pt. 2, p. 49-112.

, 1975. British Lower Cretaceous Coccoliths, I, Gaut Clay, Paleontogr. Soc. Mono., p. 113-142.

Black, M., and Barnes, B., 1959. The structure of coccoliths from the English Chalk: Geol. Mag., v. 96/5, p. 321-328.

Bramlette, H. H. and Martini, E., 1964. The great change in calcareous nannoplankton fossils between the Maestrichtian and Danian: Micropaleontology, v. 10, p. 291-322.

Briden, J. C., Drewry, G. E., and Smith, A. G., 1973. Phanerozoic equal-area world maps: J. Geol., v. 82, p. 55-574.

Brönnimann, P., 1955. Microfossils incertae sedis from the Upper Jurassic and Lower Cretaceous of Cuba: Micropaleontology, v. 1, p. $28-51$.

Bukry, D., 1969. Upper Cretaceous coccoliths from Texas and Europe: Univ. Kansas Paleontol. Contrib. Art., 51 (Protista 2), p. $1-70$.

, 1971. Cenozoic calcareous nannofossils from the Pacific Ocean: San Diego Soc. Nat. History Trans., v. 16, p. 303-327.

1973. Coccolith stratigraphy, eastern equatorial Pacific,

Leg 16, Deep Sea Drilling Project. In van Andel, T. H., Heath, G. R., et al., Initial Reports of the Deep Sea Drilling Project, Volume 16: Washington (U.S. Government Printing Office), p. 653-711.

P 1975. Coccoliths and silicoflagellate stratigraphy, Northwestern Pacific ocean, Deep Sea Drilling Project Leg 32. In Larson, R. L., Moberly, R., et al., Initial Reports of the Deep Sea Drilling Project, Volume 32: Washington (U.S. Government Printing Office), p. 677-701.

, 1976. Coccolith stratigraphy of the Manihiki Plateau, Central Pacific, Deep Sea Drilling Project, Site 317. In Jackson, E. D., Schlanger, S., et al., Initial Reports of the Deep Sea Drilling Project, Volume 33: Washington (U.S. Government Printing Office), p. 493-501.

Bukry, D., and Bramlette, M. N., 1970. Coccolith age determinations, Deep Sea Drilling Project Leg 3. In Maxwell, E., von Herzen, R., et al., Initial Reports of the Deep Sea Drilling Project, Volume 3: Washington (U.S. Government Printing Office), p. 589-611.
Cita, M. B. and Gartner, S., 1971. Deep sea Upper Cretaceous from the Western North Atlantic: 2nd Plank. Conf. Proc., v. 1, p. 287-319.

Cita, M. B. and Pasquaré, G., 1959. Studi stratigrafici sul sistema cretaceo in Italia. Nota IV. Osservazioni micropaleontologiche sul cretaceo delle Dolomiti: Riv. Ital. Paleont. Stratigr., v. 65, p. 231-250.

Deflandre, G., 1953. Hétérogénité intrinsèque et pluralité des éléments dans les coccolites actuels et fossiles: $C$. R. Acad. Sci., Paris, v. 237, p. 1785-1787.

_ 1963. Sur les Microrhabdulidés, famille nouvelle de nannofossiles calcaires: C. R. Acad. Sci., Paris, v. 256, p. 3484-3486.

Deflandre, G., and Fert, C., 1954. Observations sur les Coccolithophorides actuels et fossiles en microscopie ordinaire et électronique: Ann. Paléontologie, v. 40, p. 115-176.

Douglas, R. G., 1972. Paleozoogeography of late Cretaceous planktonic foraminifera in North America, J. Foram. Res., v. 2 , p. 14-34.

Douglas, R. G. and Savin, S. M., 1976. Oxygen and carbon isotope analyses of Tertiary and Cretaceous microfossils from Shatsky Rise and other sites in the North Pacific Ocean. In Larson, R. L., Moberly, R., et al., Initial Reports of the Deep Sea Drilling Project, Volume 32: Washington (U.S. Government Printing Office), p. 509-520.

Edwards, A. R., 1973. Southwest Pacific regional unconformities encountered during Leg 21. In Burns, R. E., Andrews, J. E., et al., Initial Reports of the Deep Sea Drilling Project, Volume 21: Washington (U.S. Government Printing Office), p. 701-720.

Fauvre, G. and Powell, J. L., 1972. Strontium isotope geology: (Springer Verlag), New York, Heidelberg, Berlin.

Garrels, R. M. and Perry, E. A., 1975. Cycling of carbon, sulfur, and oxygen through geologic time. In Goldberg, E. D. (Ed.), The Sea: v. 5, p. 303-336.

Gartner, S., 1968. Coccoliths and related calcareous nannofossils from Upper Cretaceous deposits of Texas and Arkansas: Univ. Kansas Paleontol. Contr. Art., 48 (Protista 1), p. 1-56.

Goldman, J.C., 1972.The kinetics of inorganic carbon limited growth of green algae in continuous cultur: its relationship to eutrophication, Ph.D. thesis, U.C. Berkeley.

Gorka, H. 1957. Les Coccolithophoridés du Maestrichtian supérieur de Pologne: Acta Paleont. Polonica, v. 2, p. 235-284.

Grün, W. and Allemann, F., 1975. The lower Cretaceous of Carabaca (Spain). Berriasian calcareous nannoplankton of the Mitravetes Section (Subbetic Zone, Prov. Murcia): Eclog. Geol. Helv., v. 68, p. 147-211.

Hay, W.W.., 1972. Probabilistic stratigraphy: Eclog. Geol. Helv., v. 65 , p. $225-266$.

Hays, J. D. and Pitman, W. C., 1973. Lithospheric plate motion, sea level changes and climatic and ecological consequences, Nature, v. 246 , p. $18-22$.

Hill, M. E., 1976. Lower Cretaceous calcareous nannofossils from Texas and Oklahoma: Palaeontographica Abt. B, Lfg. 4-6, p. 103-179.

Jarrard, R. D., 1974. Paleomagnetism of some Leg 27 sediment cores. In Heirtzler, Veevers, J., et al., Initial Reports of the Deep Sea Drilling Project, Volume 27: Washington (U.S. Government Printing Office), p. 415-423.

Kamptner, E., 1938. Einige Bemerkungen über Nannoconus: Paläont. Zeitschr., v. 20, p. 249-257.

Lapparent, J. de, 1931. Sur les prétendus "embryons de Lagena"' C. R. Soc. Géol. France, 1931, p. 22-223.

Larson, R. L. and Hilde, T. W. C., 1975. A revised time scale of magnetic reversals for the early Cretaceous and late Jurassic. $J$. Geophys. Res., v. 80, p. 2586-2594. 
Larson, R. L. and Pitman, W. C., 1972. World-wide correlation of Mesozoic magnetic anomalies, and its implications: Geol. Soc. Am. Bull., v. 83, p. 3645-3662.

Lambert, R. S. J., 1973. The pre-Pleistocene Phanerozoic time-scale - a review in: Harlan, W. B. and Francis, E. H. (Eds.), The Phaerozic time-scale-a supplement, pt. I: (Spec. Publ. Geol. Soc. London, n. 5 p. 9-34.

Manheim, F., Rowe, G. T., and Jipa, D., 1975. Marine phosphorite formation off Peru: J. Sed. Petrol., v. 45, p. 243-251.

Manivit, H., 1965. Nannofossiles calcaires de l'Albo-Aptica: Rev. Micropal., v. 8, p. 189-201.

, 1966. Sur quelques coccolithes nouveaux du Néocomien: C. R. Soc. Géol. France, v. 7, p. 267-268.

— 1971. Nannofossiles calcaires du Crétacé Français (Aptien-Maestrichtion): Fac. Sci. d'Orsay, Thèse Doctorat d'Etat.

Manivit, H., Perch-Nielsen K., Prins, B., and Verbeek, J. W., 1977. Mid-Cretaceous calcareous nannofossil biostratigraphy. Koninkl. Nederl. Akad. We hettschappen Amsterdam Proc., ser. B, v. 80 , no. 3 , p. $169-181$.

McIntyre, A., and McIntyre, R., 1971. Coccolith concentrations and differential solution in oceanic sediments. In Funnell, B. M. and Riedel, W. R. (Eds.), The micropalaeontology of oceans: Cambridge, (Cambridge University Press), p. 253-261.

Noël, D., 1957. Coccolithes des terrains jurassiques de l'Algérie: Publ. Serv. Carte Géol. Algérie, v. 2, p. 303-385. , 1959. Étude de Coccolithes du Jurassique et du Crétacé inférieur: Publ. Serv. Carte Géol. Algérie, v. 2, p. 155-196.

, 1965. Sur les Coccolithes du Jurassique Européen et d'Afrique due Nord. Essai de Classification des Coccolithes Fossiles: Centre Nat. Rech. Sci., Paris, p. 209.

, 1970. Coccolithes crétacés: la craie campanienne du Bassin de Paris: Centre Nat. Rech. Sci., Paris, p. 129.

Obradovich, J. D. and Cobban, W. H., 1975. A time-scale for the late Cretaceous of the Western Interior of North America: Geol. Assoc. Canada Spec. Paper, 13, p. 31-54.

Paasche, E., 1964. A tracer study of the carbon uptake during coccolith formation and photosynthesis in the coccolithophorid Coccolithus huxleyi. Physolog. Plantarum, Suppl. III, p. 5-82.

- 1968. Biology and physiology of coccolithophorids: Ann. Rev. Microbiol., v. 22, p. 71-86.

Perch-Nielsen, K., 1968. Der Feinbau und die Klassifikation der Coccolithen aus dem Maastrichtien von Dänemark: Kong. Dnske Vidensk. Selsk. Biol. Skr. v. 16, no. 1. , 1969. Die Coccolithen einiger dänischer Maastrichtien-und Danienlokälitaten: Medd. Dansk Geol. Foren. Kobenhaven, v. 51, p. 51-68.

Piper, D. Z. and Codispoti, L. A., 1975. Marine phosphorite deposits and the nitrogene cycle: Science, v. 188, p. 15-18.

Reinhardt, P., 1964. Einige Kalkflagellaten-Gattungen (Coccolithophoriden, Coccolithineen) aus dem Mesozoikum Deutschlands: Monatsber. Dt. Akad. Wiss. Berlin, v. 6, p. 749-759.

, 1965. Neue Familien für fossile Kalkflagellaten (Coccolithophoriden, Coccolithineen): Monatsber. Dr. Akad. Wiss. Berlin, v. 7 , p. $30-40$.

, 1966. Zur Taxionomic und Biostratigraphie des fossilen Nannoplanktons aus dem Malm, der Kreide und dem Alttertiär Mitteleuropas: Freiberger Forschungsh., v. C196, p. 5-63.

, 1970. Synopsis der Gattungen und Arten der mesozoischen Coccolithen und anderer kalkiger Nannofossilien, Teil II. Freiberger Forschungsh: v. C265, p. 43-110.

Rood, A.P., Hay, W.W., and Barnard,T., 1971. Electron microscope studies of oxford clay coccoliths: Eclog. Geol. Helv., v. 64 , p. $245-272$.
Roth, P. H., 1973. Calcareous nannofossils - Leg 17, Deep Sea Drilling Project. In Winterer, E.L., Ewing, J.I., et al., Initial Reports of the Deep Sea Drilling Project, Volume 17: Washington (U.S. Government Printing Office), p. 695-795. 1975. Calcareous nannofossils and the Cretaceous oceans. Abstracts with programs: Geolog. Soc. Am., Ann. Meetings, v. 7, p. 1253.

, in press. Cretaceous calcareous nannofossil diversity and paleoceanography: Fourth Internat. Palynolog. Conf. Proc., 1976, Lucknow.

Roth, P.H. and Berger, W.H., 1975. Distribution and dissolution of coccoliths in the South and Central Pacific: Cushman Found. Foram. Res., Spec. Publ. 13.

Roth, P.H. and Thierstein, H., 1972. Calcareous nannoplankton: Leg 14 of the Deep Sea Drilling Project. In Hayes, D.E., Pimm, A.C., et al., Initial Reports of the Deep Sea Drilling Project, Volume 14: Washington (U.S. Government Printing Office), p. 421-485.

Roth, P.H., Wise, S.W., and Thierstein, H., 1975. Early chalk diagenesis and lithification: Sedimentological applications of paleontological approaches: Ninth Internat. Sediment. Cong., Nice, 1975, v. 7, p. 187-199.

Savin, S.M., 1977. The history of the earth's surface temperature during the past 100 million years, Ann. Rev. Earth Planet. Sci., v. 5 , p. $319-355$.

Schlanger, O., Douglas, W.R.G., Lancelot, Y., Moore, T.C., and Roth, P.H., 1973. Fossil preservation and diagenesis of pelagic carbonates from the Magellan Rise, central North Pacific Ocean. In Winterer, E.L., Ewing, J.I., et al., Initial Reports of the Deep Sea Drilling Project, Volume 17, Washington (U.S. Government Printing Office), p. 407-427.

Sclater, J.G., Jarrard, R.D., McGowran, B., and Gartner, S., 1974. Comparison of the magnetic and biostratigraphic time scales since the Late Cretaceous. In von der Borch, C.C., Sclater, J.G., et al., Initial Reports of the Deep Sea Drilling Project, Volume 22: Washington (U.S. Government Printing Office), p. 381-386.

Shuey, R.T., Brown, F.H., Eck, G.G., and Howell, F.C., in press. A statistical approach to temporal biostratigraphy. In Bishop, W.W., (Ed.), Geological Background to Fossil Man: London (Duckworth).

Stover, L.E, 1966. Cretaceous coccoliths and associated nannofossils from France and the Netherlands: Micropaleontology, v. 12, p. 133-167.

Stradner, H., 1962. Ueber neue und wenig bekannte Nannofossilien aus Kreide und Alttertiär: Verh. Geol. Bundesanst. Wien, v. 2, p. 363-377.

1963. New contributions to Mesozoic stratigraphy by means of nannofossils: Sixth World Petrol Congr. Proc. (Frankfurt a. M.) sect. 1, paper 4.

Stradner, H., Adamiker, D., and Maresch, O., 1968. Electron microscope studies on Albian calcareous nannoplankton from the Delft 2 and Leidschendam 1 Deepwells, Holland: Verh. Nederl. Akad. Weetensch., Afd. Natururk., Eerste Reeks, Deel XXIV/4

Thierstein, H.R., 1971. Tentative Lower Cretaceous calcareous nannoplankton zonation: Eclog. Geol. Helv., v. 64, p. 459-488.

, 1973. Lower Cretaceous nannoplankton biostratigraphy: Abhand. Geol. Bundesanst (Wien), v. 29, p. 1-52.

, 1974. Calcareous nannoplankton Leg 26. In Davies, T.A., Luyendyk, B.P., et al., Initial Reports of the Deep Sea Drilling Project, Volume 26: Washington (U.S. Government Printing Office), p. 619-667.

1976. Mesozoic calcareous nannoplankton biostratigraphy of marine sediments. Marine Micropaleontol., v. 1 , p. $325-362$. 
Trejo, M., 1959. Dos nuevas especies del geńero Nannoconus (Protozoa, inc. sed.): Ciencia (Méx.), v. 19, p. 130-132.

, 1969. Conusphaera mexicana, un nuevo coccolithoforido del Jurasico Superior del Mexico: Rev. Inst. Mexicano del Petroleo, v. 1, p. 5-15.

van Hinte, J.E., 1976a. A Cretaceous time scale: Am. Assoc. Petrol.Geol., v. 60 , no. 4 , p. $498-516$.

1976b. A Jurassic time scale: Am. Assoc. Petrol. Geol., v. 60 , no. 4, p. $489-497$.

Veeh, H.W., Burnett, W.C., and Soutar, A., 1973. Contemporary phosphorites on the continental margin of Peru: Science, v. 181, p. 844-845.

Verbeek, J.W., 1976. Upper Cretaceous calcareous nannoplankton zonation in a composite section near El Kef, Tunesia. I and II:
Koninkl. Nederl. Akad. Wettenschappen, Amsterdam, Proc., ser. B, v. 79, p. 129-148.

Wilcoxon, J.A., 1972. Calcareous nannoplankton ranges. In Hollister, C.D., Ewing, J.I., et al., Initial Reports of the Deep Sea Drilling Project, Volume 11: Washington (U.S. Government Printing Office), p. 459-473.

Worsley, T., 1971. Calcareous nannofossil zonation of Upper Jurassic and Lower Cretaceous sediments from the Western Atlantic: Second Plankt. Conf. Proc., Roma 1970, v. 2, p. 1301-1322.

, 1974. The Cretaceous-Tertiary boundary event in the Ocean. In Hay, W.W. (Ed.), Studies in Paleo-oceanography: Soc. Econ. Paleont. Mineral. Spec. Publ., v. 20, p. 94-125.

Worsley, T.R. and Martini, E., 1971. Late Maastrichtian nannoplankton provinces: Nature, v. 225, p. 1242-1243. 



\section{PLATE 1}

Magnification $2000 \times$, except for Figures $3 b$, and 7 b-d which are $1000 \times$.

(XN: cross-polarized light; $\mathrm{PH}$ : phase contrast, OL: ordinary light)

Figure 1 Retecapsa neocomiana Black, 1971; Sample 391C-37-2, $75 \mathrm{~cm}$.
1a. $\mathrm{XN}$.
1b. $\mathrm{PH}$.
1c. OL.

Figure 2 Retecapsa brightonii Black, 1971; Sample 391C-24-1, $75 \mathrm{~cm}$.

2a. XN.
2b. PH.
2c. OL.

Figure 3 Retecapsa angustiforata Black, 1971; Sample 391C-24-6, $120 \mathrm{~cm}$.

3a. XN.

3b. PH; Sample 391C-24-6, $120 \mathrm{~cm}$.

Figure 4 Retecapsa angustiforata Black, 1971; Sample 391C-15-3, $70 \mathrm{~cm}$.

4a. XN.

4b. $\mathrm{PH}$.

4c. OL.

Figure 5 Retecapsa angustiforata Black, 1971; Sample 391C-16-4, $132 \mathrm{~cm}$.

5a. XN.

5b. $\mathrm{PH}$.

$5 c \mathrm{OL}$.

Figure 6 Cruciellipsis cuvillieri (Manivit, 1966) Thierstein, 1971; Sample 391C-17-1, $66 \mathrm{~cm}$. OL.

Figure $7 \quad$ Cruciellipsis chiasta (Worsley, 1971) Thierstein, in Roth and Thierstein, 1972 (Black, 1971)

n. comb.; Sample 391C-15-3, $70 \mathrm{~cm}$.

7a. $\mathrm{PH}$.

7b. XN.

7c. $\mathrm{XN}$.

7d. OL.

Figure 8 Cyclagelosphaera margareli Noël, 1965; Sample 391C-36-2, $53 \mathrm{~cm}$.

8a. XN.

Figure 9 Watznaueria britannica (Stradner, 1963) Reinhardt, 1964; Sample 391C-15-3, $70 \mathrm{~cm}$. XN.

Figure $10 \quad$ Stephanolithion laffittei Noël, 1965. Sample 391C-15-2, $78 \mathrm{~cm}$.

10a. OL.

10b. PH.

Figure 11 Corrollithion ellipticum Bukry, 1969. Sample 391C-20-1, $135 \mathrm{~cm}$.

11a. XN.

11b. $\mathrm{PH}$.

Figure 12 Assipetra infracretacea (Thierstein, 1973) Roth, 1973. Sample 391C-44-6, $95 \mathrm{~cm}$.

$12 \mathrm{a}, \mathrm{b}, \mathrm{XN}$.

12c. $\mathrm{PH}$.

Figure 13 Rucinolithus wisei Thierstein, 1971. Sample 391C-21-4, $96 \mathrm{~cm}$.

13a. XN.

13b. XN

13c. $\mathrm{PH}$. 
PLATE 1

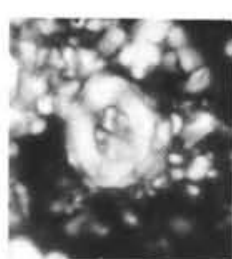

$1 \mathrm{a}$

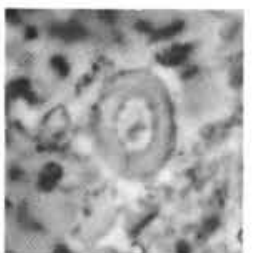

$1 \mathrm{~b}$

$391 \mathrm{C}-37-2,75 \mathrm{~cm}$

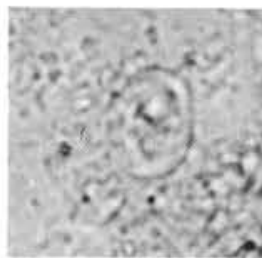

$1 \mathrm{c}$

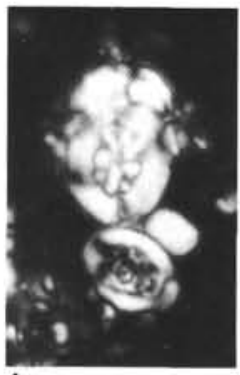

$3 b$

$3 a$

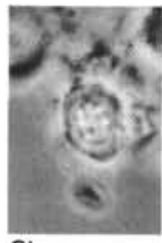

391C-24-6, $120 \mathrm{~cm}$

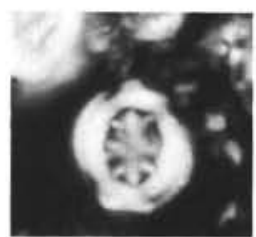

$5 a$

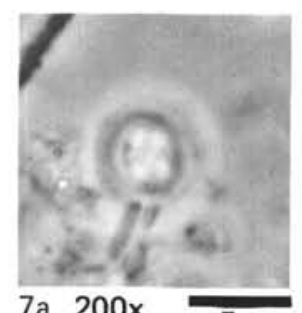

7a $200 x$

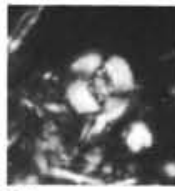

$391 \mathrm{C}-15-3$

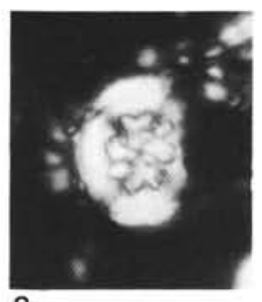

$2 a$

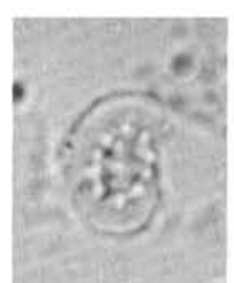

$2 \mathrm{~b}$

$391 \mathrm{C}-24-1,75 \mathrm{~cm}$

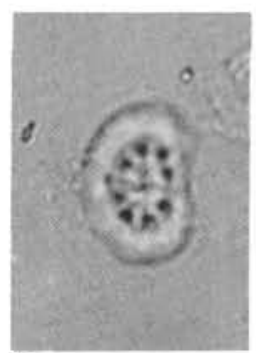

2c

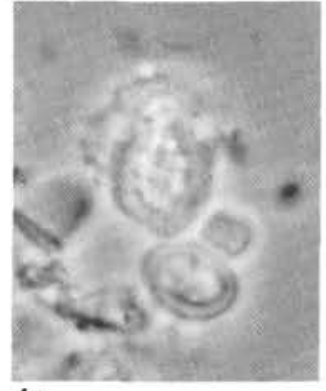

$4 \mathrm{c}$

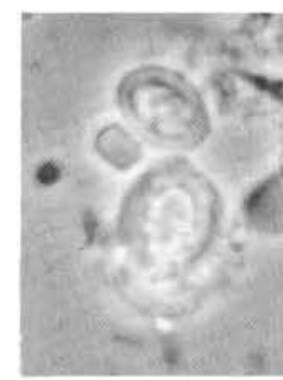

4b $391 \mathrm{c}-15-3$

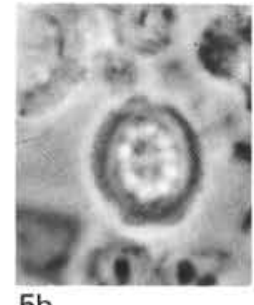

$5 b$

$391 \mathrm{C}-16-4,132 \mathrm{~cm}$

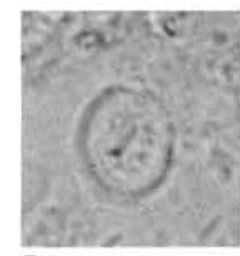

$5 c$

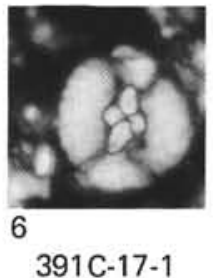

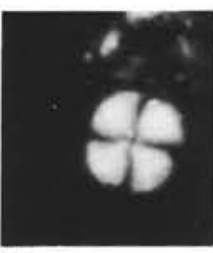

$8 a$
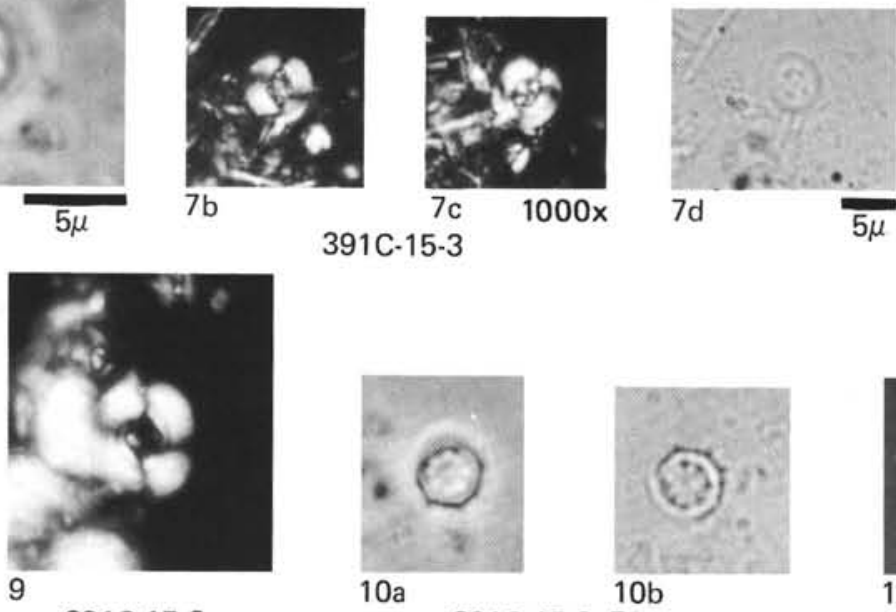

391C-15-3
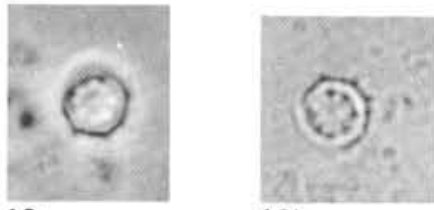

$10 \mathrm{~b}$

$10 \mathrm{a}$

$391 \mathrm{C}-15-2,78 \mathrm{~cm}$

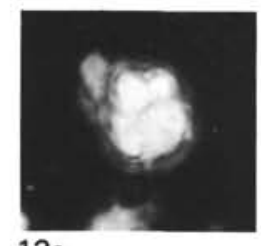

$12 \mathrm{a}$

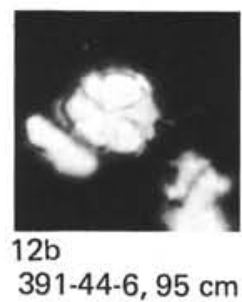

$12 \mathrm{c}$

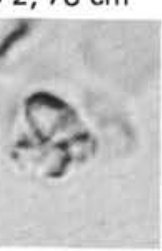

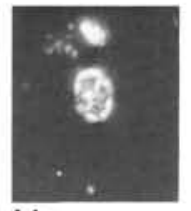

$11 a$

$391 \mathrm{C}-20-1,135 \mathrm{~cm}$

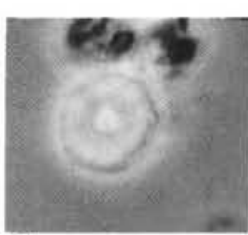

$8 b$

$391 \mathrm{C}-36-2,53 \mathrm{~cm}$

$391-44-6,95 \mathrm{~cm}$

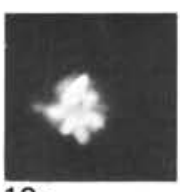

$13 a$

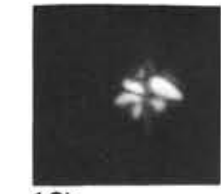

$13 \mathrm{~b}$

$391 \mathrm{C}-21-4,96 \mathrm{~cm}$

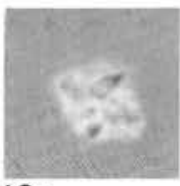

$13 c$ 


\section{PLATE 2}

Magnification: $2000 \times$. (XN: cross-polarized light,

$\mathrm{PH}$ : phase contrast, OL: ordinary light)

Figure 14

Conusphaera mexicana Trejo, 1969, Sample $391 \mathrm{C}-44-6,95 \mathrm{~cm}$.

14a. XN.

14b. PH.

Figure 15 Nannoconus bucheri Brönnimann, 1955. Sample $391 \mathrm{C}-43-1,13 \mathrm{~cm}$.

15a. XN.

15b. PH.

15c. OL.

Figure 16 Nannoconus colomii (Lapparent, 1931) Kamptner, 1938. Sample 391C-21-4, $96 \mathrm{~cm}$.

16a. XN.

16b. PH.

16c. OL.

Figure 17 Micrantholithus obtusus Stradner, 1962. Sample $391 \mathrm{C}-17-1,66 \mathrm{~cm}$.

17a. XN.

17b. $\mathrm{PH}$.

17c. OL.

Figure 18 Parhabdolithus infinitus (Worsley, 1971) Thierstein, in Roth and Thierstein, 1972. Sample 391C-15-2, 78 $\mathrm{cm}$.

Figure 19 Manivitella aff. M. pemmatoides (Deflandre ex Manivit) Thierstein, 1971. This unusual form has a central area filled with four (or more) calcite plates; it might be a new and undescribed species. Sample $391 \mathrm{C}-16-4,132 \mathrm{~cm}$. XN.

Figure 20 Zygodiscus diplogrammus (Deflandre and Fert) Gartner, 1968. Sample 391C-16-4, $143 \mathrm{~cm}$.

20a. XN.

20b. $\mathrm{PH}$.

20c. OL.

Figure $21 \quad$ Zygodiscus cf. erectus (Deflandre and Fert, 1954) Manivit, 1971, Sample 391C-15-2, $78 \mathrm{~cm}$.

21a. XN.

21b. PH.

21c. OL.

Figure 22 Parhabdolithus embergeri (Noël, 1959) Stradner, 1963. Sample 391C-15-3, $70 \mathrm{~cm}$.

22a. XN.

22b. OL.

22c. $\mathrm{PH}$. 
PLATE 2

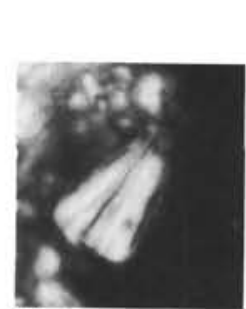

$14 \mathrm{a}$

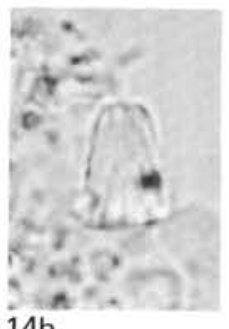

$14 b$ $391 \mathrm{C}-44-6,95 \mathrm{~cm}$

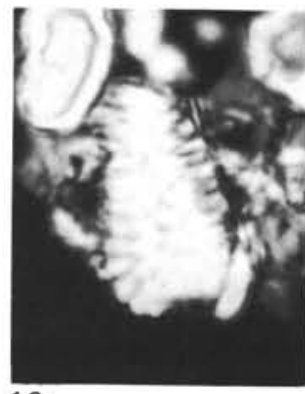

$16 a$

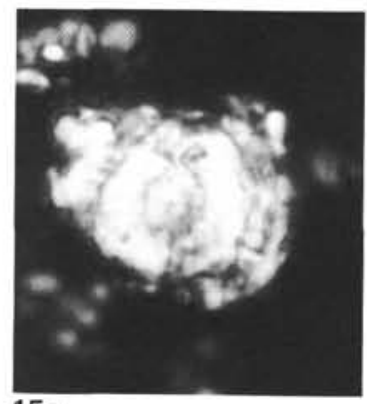

$15 a$

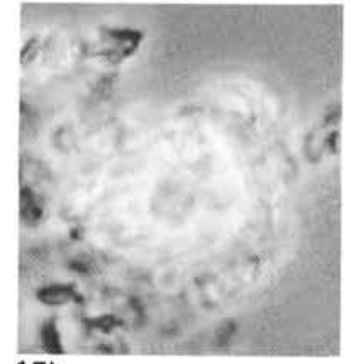

$15 b$

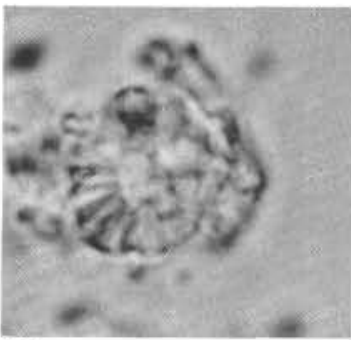

$15 c$

$391 \mathrm{C}-43-1,131 \mathrm{~cm}$

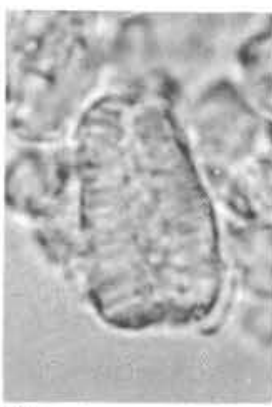

$16 \mathrm{~b}$

$391 \mathrm{C}-21-4,96 \mathrm{~cm}$

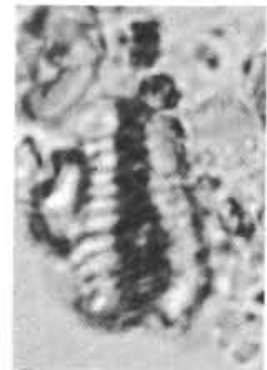

$16 \mathrm{c}$

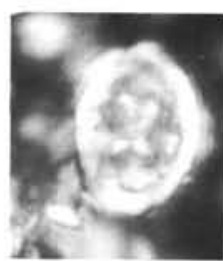

$18 \mathrm{a}$

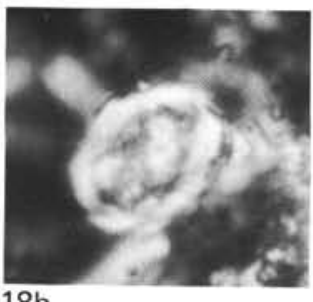

$18 \mathrm{~b}$

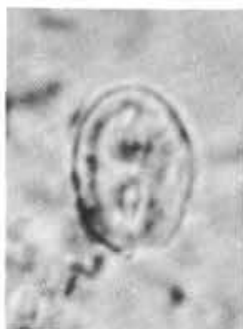

$18 \mathrm{c}$

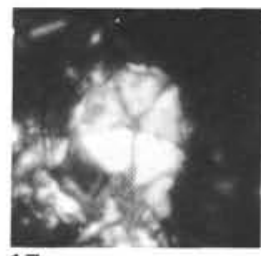

$17 a$

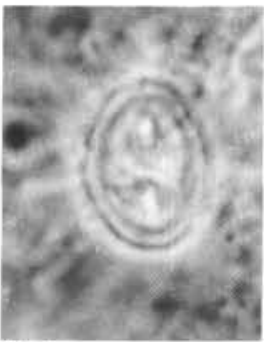

$18 d$

$391 \mathrm{C}-15-2,78 \mathrm{~cm}$

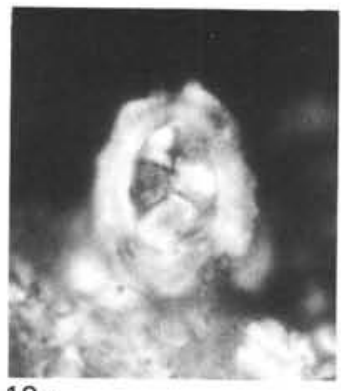

$19 a$

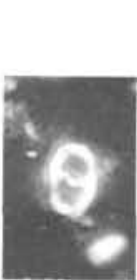

$21 \mathrm{a}$

$21 \mathrm{~b}$

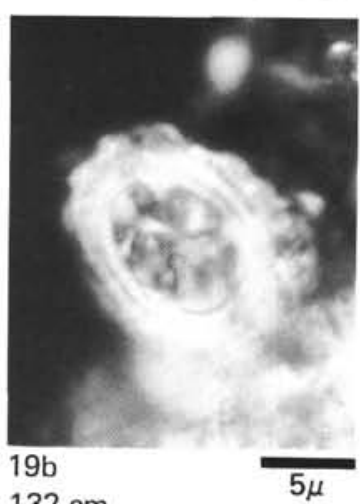

$391 \mathrm{C}-16-4,132 \mathrm{~cm}$

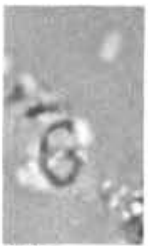

$391 \mathrm{c}-15-2,73 \mathrm{~cm}$

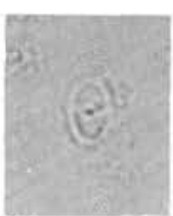

21c

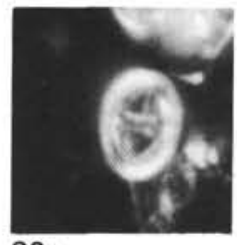

$20 a$
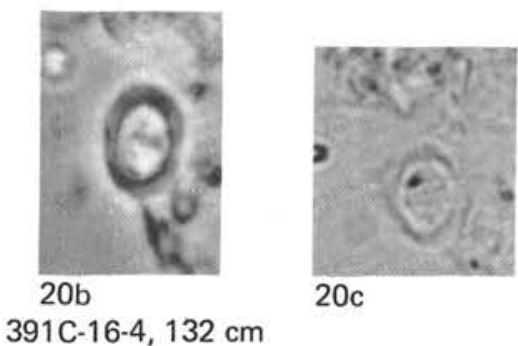

20c

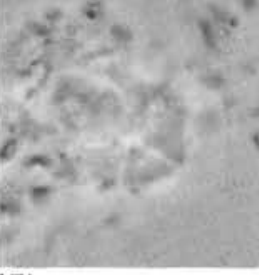

$17 b$

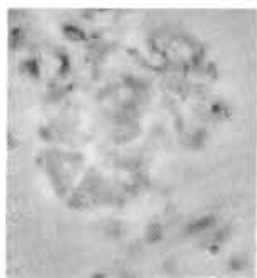

$17 \mathrm{c}$

$391 \mathrm{C}-17-1,66 \mathrm{~cm}$

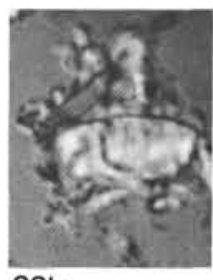

391C-15-3

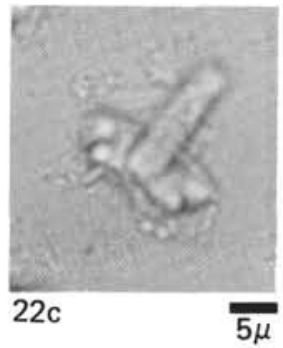




\section{PLATE 3}

Scanning electron micrographs of $\mathrm{Au} / \mathrm{Pd}$ coated specimens.

Tilt of stage $0^{\circ}$. Scale bar $=1 \mu \mathrm{m}$.

Figure 1 Lithraphidites praequadratus n. sp. Holotype. Sample: 44-390A-13-3, $106 \mathrm{~cm}$. Negative Number UUMN 55.

Figure 2 Lithraphidites praequadratus n. sp. Paratype. Sample: 390H-13-3, $106 \mathrm{~cm}$. Negative Number UUMN 51.

Figure 3 Lithraphidites praequadratus n. sp. Paratype. Sample: 44-390A-13, $3 \mathrm{~cm}$. Negative Number UUMN 58.

Figure 4 Transitional form between Lithraphidites praequadratus $\mathrm{n}$. sp. and $L$. quadratus, closer to $L$. praequadratus $\mathrm{n}$. sp. next to it Tetralithus aculeus. Sample 44-390A-13-3, $106 \mathrm{~cm}$. Negative Number UUMN 54.

Figure 5 Lithraphidites quadratus Sample 22-217-17-1, $20 \mathrm{~cm}$. Indian Ocean. Upper Maestrichtian.

Figure 6 Lithraphidites carniolensis Sample 17-167-45, CC. Pacific Ocean. Tetralithus trifidus Zone. (Micrograph by J. Bowdler, University of Utah.) 
PLATE 3
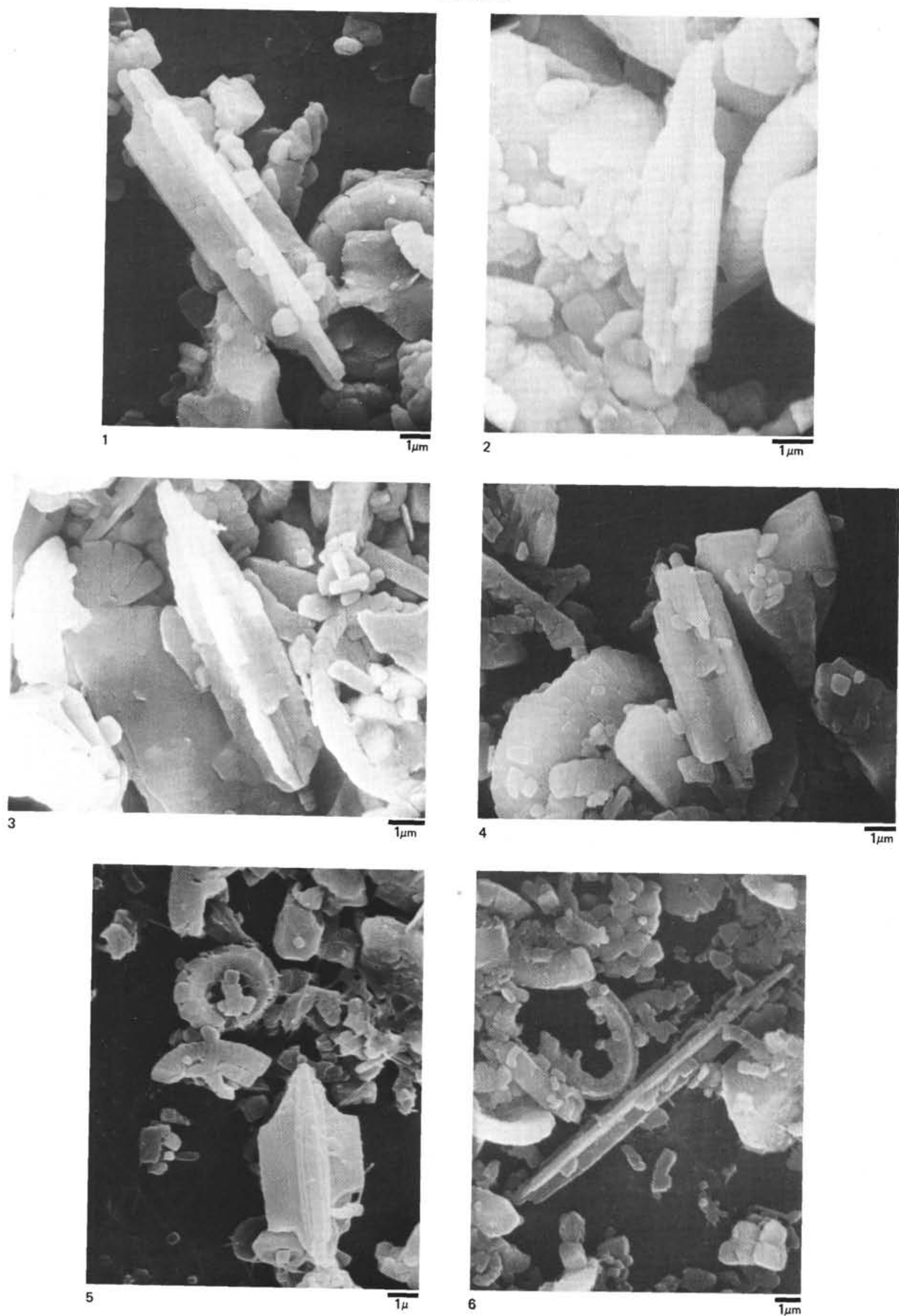